\title{
Antispasmodic Effect of Essential Oils and Their Constituents: A Review
}

\author{
Simona Codruta Heghes ${ }^{1}$, Oliviu Vostinaru ${ }^{2, *}$, Lucia Maria Rus ${ }^{1}$, Cristina Mogosan ${ }^{2}$, \\ Cristina Adela Iuga $1,3(1)$ and Lorena Filip 4
}

1 Department of Drug Analysis, Iuliu Hatieganu University of Medicine and Pharmacy, Cluj-Napoca 400349, Romania; cmaier@umfcluj.ro (S.C.H.); lrus@umfcluj.ro (L.M.R.); iugac@umfcluj.ro (C.A.I.)

2 Department of Pharmacology, Physiology and Physiopathology, Iuliu Hatieganu University of Medicine and Pharmacy, Cluj-Napoca 400349, Romania; cmogosan@umfcluj.ro

3 Department of Proteomics and Metabolomics, MedFuture Research Center for Advanced Medicine, Iuliu Hatieganu University of Medicine and Pharmacy, Cluj-Napoca 400349, Romania

4 Department of Bromatology, Hygiene, Nutrition, Iuliu Hatieganu University of Medicine and Pharmacy, Cluj-Napoca 400349, Romania; lfilip@umfcluj.ro

* Correspondence: oliviu_vostinaru@yahoo.com; Tel.: +40-074-118-5163

Academic Editor: Francesca Mancianti

Received: 29 March 2019; Accepted: 25 April 2019; Published: 29 April 2019

\begin{abstract}
The antispasmodic effect of drugs is used for the symptomatic treatment of cramping and discomfort affecting smooth muscles from the gastrointestinal, billiary or genitourinary tract in a variety of clinical situations.The existing synthetic antispasmodic drugs may cause a series of unpleasant side effects, and therefore the discovery of new molecules of natural origin is an important goal for the pharmaceutical industry. This review describes a series of recent studies investigating the antispasmodic effect of essential oils from 39 plant species belonging to 12 families. The pharmacological models used in the studies together with the mechanistic discussions and the chemical composition of the essential oils are also detailed. The data clearly demonstrate the antispasmodic effect of the essential oils from the aromatic plant species studied. Further research is needed in order to ascertain the therapeutic importance of these findings.
\end{abstract}

Keywords: essential oils; aromatic plants; antispasmodic effect; isolated ileum; monoterpenes

\section{Introduction}

The antispasmodic (spasmolytic) effect of drugs is commonly used for the reduction of excessive smooth muscle contractility, responsible for cramping and discomfort in the abdominal area, caused by multiple conditions affecting the gastrointestinal, biliary or genitourinary tract [1]. Irritable bowel syndrome (IBS), biliary colic caused by gallstones, gastritis, colitis and pancreatitis or dysmenorrhea may affect large numbers of patients and usually require antispasmodic treatment for the relief of symptoms [1-3]. Additionally, antispasmodic compounds are also used for the reduction of discomfort caused by medical procedures like colonoscopy [4]. A variety of synthetic antispasmodic drugs have been authorized worldwide by the regulatory agencies, the most important being anticholinergic agents (butylscopolamine), direct smooth muscle relaxants (papaverine), calcium antagonists (pinaverium) or opioid receptor modulators (trimebutine) [1,2]. Despite their clinical efficacy, the use of these molecules is often limited by the development of unpleasant and sometimes severe side effects which may reduce patient compliance and impair treatment efficiency [1,4]. Historically, a long time before the golden age of medicinal chemistry, several aromatic plants were used in traditional medicine for the treatment of different ailments in some parts of the world. In Europe, aromatic plants like peppermint or thyme have been used for medical purposes since antiquity while in Chinese or Indian traditional medicine other 
aromatic species like cinnamon or sandalwood were known for centuries [5]. Nowadays, antispasmodic botanical remedies are used by a constantly increasing number of patients for symptomatic treatment of functional dyspepsia, intestinal, colonic or ureteral spasms, gallbladder hyperactivity and uterine cramps [6]. In the large category of medicinal plants, aromatic plants rich in essential oils are considered a valuable and easily accessible natural resource for the development of new molecules capable of becoming drug candidates. Essential oils are complex mixtures containing mainly aromatic terpenes classified in monoterpenes and sesquiterpenes according to the number of isoprene units but also phenylpropanoid compounds. These compounds are secondary metabolites formed by isoprenoid pathways in specialized secretory tissues of aromatic plants and diffused at the surface of their flowers or leaves [7]. The biological effects of essential oils have been extensively researched, as they can easily pass through cellular membranes and influence a variety of molecular targets from ion channels to intracellular enzymes [8]. Multiple in vitro and in vivo studies have confirmed the anti-oxidant, antimicrobial, antifungal, antiparasitary, anti-inflammatory, antinociceptive or antitumoral effects of essential oils [7], but the antispasmodic effect has been less studied experimentally, despite being mentioned in traditional medicine sources. Hence, this review was aimed at the investigation of the antispasmodic effect of essential oils, presenting the experimental models used for pharmacological testing with the subsequent mechanistic explanations, but also the chemical composition of the studied essential oils.

\section{Methodology}

A search was performed in Web of Science, PubMed and Scopus scientific databases, including the last 20 years (1998-2018). The search terms "essential oils" and "antispasmodic" ("spasmolytic") were used for data selection. Only articles in English were included in this work. Our study investigated the antispasmodic effect of the essential oils and was not focused on the bronchodilator and vasodilator effects, presented by other reviews.

\section{Results and Discussion}

\subsection{Preclinical Studies Investigating Antispasmodic Effect of Essential Oils}

This review showed that essential oils from thirty-nine plant species belonging to twelve families presented antispasmodic properties demonstrated by specific animal models. The plants were organized alphabetically by family and botanical name, the proposed antispasmodic mechanism being also presented, where available. The families with the highest proportion of plant species showing antispasmodic effects due to essential oils (EO) were Lamiaceae (13 species), Apiaceae (6 species), and Asteraceae ( 5 species). Other identified families were Annonaceae and Poaceae (3 species), Rutaceae and Verbenaceae (2 species) while Anacardiaceae, Araceae, Geraniaceae, Rosaceae and Zingiberaceae families each presented only one plant species with antispasmodic essential oil (Table 1). 
Table 1. Plant species containing essential oils with antispasmodic activity demonstrated in preclinical studies.

\begin{tabular}{|c|c|c|c|c|}
\hline No. & Plant Species with Essential Oils & $\begin{array}{l}\text { Experimental Model/Concentration of EO } \\
\text { in Organ Bath }\end{array}$ & Mechanism of Antispasmodic Effect & Reference \\
\hline 1. & $\begin{array}{c}\text { Anacardiaceae } \\
\text { Pistacia integerrima—zebrawood } \\
\text { Annonaceae }\end{array}$ & Isolated guinea pig ileum $/ 50 \mu \mathrm{g} / \mathrm{mL}$ & Inhibition of $\mathrm{Ca}^{2+}$ channels & Shirole et al., 2015 [9] \\
\hline 2. & Cananga odorata var. genuina-ylang ylang & $\begin{array}{l}\text { Isolated rat bladder } / 0.05 \mathrm{~mL} / 20 \mathrm{~mL} \text {; white } \\
\text { rabbit bladder in vivo/0.01-0.05 mL/rabbit * }\end{array}$ & Increase of cAMP & Kim et al., 2003 [10] \\
\hline 3. & Xylopia frutescens & Isolated guinea pig ileum/3-729 g//mL & $\begin{array}{c}\text { Inhibition of } \mathrm{Ca}^{2+} \text { channels; antagonism of } \\
\text { histaminergic receptors }\end{array}$ & Souza et al., 2015 [11] \\
\hline 4 & Xylopia langsdorffiana & $\begin{array}{l}\text { Isolated guinea pig ileum; isolated rat } \\
\text { uterus } / 243-729 \mu \mathrm{g} / \mathrm{mL}\end{array}$ & Decrease in cytosolic calcium concentration & Correia et al., 2015 [12] \\
\hline 5. & $\begin{array}{l}\text { Apiaceae } \\
\text { Anethum graveolens-dill }\end{array}$ & Isolated rat ileum $/ 0.5-2 \mathrm{mg} / \mathrm{mL}$ & Inhibition of $\mathrm{Ca}^{2+}$ channels & Gharib Naseri et al., 2007 [13] \\
\hline 6. & Carum carvi-caraway & $\begin{array}{l}\text { Isolated guinea pig ileum/2.20-6.63 mg/mL; } \\
\text { Dispersed smooth muscle cells of guinea } \\
\text { pigs } / 2.5 \mathrm{mg} / \mathrm{mL}\end{array}$ & Not available & $\begin{array}{c}\text { Heinle et al., } 2006 \text { [14]; Al-Essa et al., } 2010 \\
\text { [15] }\end{array}$ \\
\hline 7. & Coriandrum sativum—coriander & $\begin{array}{c}\text { Isolated rabbit jejunum/ } \\
1-30 \mathrm{mg} / \mathrm{mL}\end{array}$ & Inhibition of $\mathrm{Ca}^{2+}$ channels & Jabeen at al., 2009 [16] \\
\hline 8. & Ferula heuffelii Griseb. & $\begin{array}{l}\text { Isolated rat ileum/ } \\
75-250 \mu \mathrm{g} / \mathrm{mL}\end{array}$ & Not available & Pavlovic et al., 2012 [17] \\
\hline 9. & Foeniculum vulgare—fennel & Isolated rat uterus $/ 10-40 \mathrm{mg} / \mathrm{mL}$ & Not available & Ostad et al., 2001 [18] \\
\hline 10. & $\begin{array}{c}\text { Pimpinella anisum-aniseed } \\
\text { Araceae }\end{array}$ & $\begin{array}{l}\text { Isolated rat anococcygeus muscle } / 5-50 \\
\mu \mathrm{g} / \mathrm{mL}\end{array}$ & Activation of NO-cGMP pathway & Tirapelli et al., 2007 [19] \\
\hline 11. & $\begin{array}{c}\text { Acorus calamus—sweet flag, calamus } \\
\text { Asteraceae }\end{array}$ & $\begin{array}{l}\text { Isolated rabbit jejunum/ } \\
\quad 0.3-1 \mathrm{mg} / \mathrm{mL}\end{array}$ & Inhibition of $\mathrm{Ca}^{2+}$ channels & Gilani et al., 2006 [20] \\
\hline 12. & Artemisia dracunculus_tarragon & $\begin{array}{l}\text { Isolated sheep ruminal and abomasal smooth } \\
\text { muscles } / 0.1-100 \mu \mathrm{g} / \mathrm{mL}\end{array}$ & Not available & Jalilzadeh-Amin et al., 2012 [21] \\
\hline 13. & Chamaemelum nobile_roman chamomile & Isolated guinea pig ileum $/ 60 \mu \mathrm{g} / \mathrm{mL}$ & Direct smooth muscle relaxation & Sandor et al., 2018 [22] \\
\hline 14. & Chrysactinia mexicana—damianita daisy & Isolated rabbit ileum $/ 30 \mu \mathrm{g} / \mathrm{mL}$ & $\begin{array}{c}\text { Inhibition of } \mathrm{Ca}^{2+} \text { channels; increase of } \\
\text { cAMP }\end{array}$ & Zavala-Mendoza et al., 2016 [23] \\
\hline 15. & Hofmeisteria schaffneri & $\begin{array}{l}\text { Gastrointestinal transit test in mouse } \\
\text { (in vivo) } / 316 \mathrm{mg} / \mathrm{kg}^{*}\end{array}$ & Not available & Perez-Vasquez et al., 2017 [24] \\
\hline 16. & $\begin{array}{c}\text { Matricaria recutita (chamomila)_German } \\
\text { chamomile } \\
\text { Geraniaceae }\end{array}$ & Isolated rabbit jejunum $/ 0.3-3 \mathrm{mg} / \mathrm{mL}$ & $\mathrm{K}^{+}$channels activation & Mehmood et al., 2015 [25] \\
\hline 17. & Pelargonium graveolens_-geranium & Isolated guinea pig ileum/ $4.8-6 \mu \mathrm{g} / \mathrm{mL}$ & $\begin{array}{l}\text { Reduction of calcium flux into the intestinal } \\
\text { smooth muscles }\end{array}$ & Lis-Balchin et al., 1997 [26] \\
\hline
\end{tabular}


Table 1. Cont

\begin{tabular}{|c|c|c|c|c|}
\hline No. & Plant Species with Essential Oils & $\begin{array}{l}\text { Experimental Model/Concentration of EO } \\
\text { in Organ Bath }\end{array}$ & Mechanism of Antispasmodic Effect & Reference \\
\hline \multicolumn{5}{|c|}{ Lamiaceae } \\
\hline 18. & Lavandula angustifolia—-true lavender & $\begin{array}{l}\text { Isolated guinea pig ileum, isolated rat } \\
\text { uterus } / 6 \mu \mathrm{g} / \mathrm{mL}\end{array}$ & Increase of cAMP & Lis-Balchin and Hart, 1999 [27] \\
\hline 19. & Melissa officinalis-melissa & $\begin{array}{c}\text { Isolated rat ileum } / 20 \mu \mathrm{g} / \mathrm{mL} ; \text { isolated mouse } \\
\text { jejunum } / 1-50 \mathrm{mg} / \mathrm{mL}\end{array}$ & Inhibition of $\mathrm{Ca}^{2+}$ channels; Not available & $\begin{array}{l}\text { Sadraei et al., } 2003 \text { [28]; Aubert et al., } 2016 \\
\text { [29] }\end{array}$ \\
\hline 20. & Mentha $x$ piperita-peppermint & $\begin{array}{c}\text { Isolated guinea pig ileum; isolated rat } \\
\text { ileum } / 10-320 \mu \mathrm{L} / \mathrm{mL}\end{array}$ & $\begin{array}{l}\text { Inhibition of } \mathrm{Ca}^{2+} \text { channels; Inhibition of } \\
5 \mathrm{HT} 3 \text { receptor channels }\end{array}$ & $\begin{array}{c}\text { Grigoleit et al., } 2005 \text { [30]; Heimes et al., } 2011 \\
\text { [31] }\end{array}$ \\
\hline 21. & Mentha spicata-spearmint & Isolated guinea pig ileum/0.1 nM-10 $\mu \mathrm{M}$ & Inhibition of $\mathrm{Ca}^{2+}$ channels & Souza et al., 2013 [32] \\
\hline 22. & Mentha $x$ villosa-mojito mint & Isolated guinea pig ileum $/ 0.9 \mu \mathrm{M}-2.5 \mu \mathrm{M}$ & Not available & De Sousa et al., 2008 [33] \\
\hline 23. & Ocimum basilicum—basil & Isolated guinea pig ileum/3-10 mg/mL & Inhibition of $\mathrm{Ca}^{2+}$ channels & Janbaz et al., 2014 [34] \\
\hline 24. & Ocimum selloi-green pepperbasil & $\begin{array}{l}\text { Isolated guinea pig ileum } / 250 \mu \mathrm{g} / \mathrm{mL}-1 \\
\mathrm{mg} / \mathrm{mL}\end{array}$ & Inhibition of $\mathrm{Ca}^{2+}$ channels & Souza et al., 2015 [35] \\
\hline 25. & Ocimum gratissimum-African basil & Isolated guinea pig ileum/0.1-1000 $\mu \mathrm{g} / \mathrm{mL}$ & Not available & Madeira et al., 2002 [36] \\
\hline 26. & Origanum majorana—sweet marjoram & $\begin{array}{c}\text { Isolated rabbit jejunum, isolated rat } \\
\text { jejunum } / 0.01-0.3 \mathrm{mg} / \mathrm{mL}\end{array}$ & Inhibition of $\mathrm{Ca}^{2+}$ channels & Makrane et al., 2018 [37] \\
\hline 27. & $\begin{array}{l}\text { Plectranthus barbatus synonym Coleus } \\
\text { forskohlii-Indian coleus }\end{array}$ & Isolated guinea pig ileum $/ 1-300 \mu \mathrm{g} / \mathrm{mL}$ & Direct smooth muscle relaxation & Camara et al., 2003 [38] \\
\hline 28. & Rosmarinus officinalis —rosemary & Isolated guinea pig ileum/150-1200 $\mu \mathrm{g} / \mathrm{mL}$ & Inhibition of $\mathrm{Ca}^{2+}$ channels & Ventura-Martinez et al., 2011 [39] \\
\hline 29. & Salvia officinalis-sage & Isolated rabbit jejunum/0.1-3 mg/mL & $\mathrm{K}^{+}$channels activation & Khan et al., 2011 [40] \\
\hline 30. & $\begin{array}{c}\text { Satureja hortensis-summer savory } \\
\text { Poaceae }\end{array}$ & Isolated rat ileum $/ 1.55 \mu \mathrm{g} / \mathrm{mL}$ & Not available & Hajhashemi et al., 2000 [41] \\
\hline 31. & Cymbopogon citratus-lemongrass & Isolated rabbit ileum/0.001-1 mg/mL & Inhibition of $\mathrm{Ca}^{2+}$ channels & Devi et al., 2011 [42] \\
\hline 32. & $\begin{array}{l}\text { Cymbopogon schoenantus (L.) } \\
\text { Spreng._camelgrass }\end{array}$ & Isolated rat ileum $/ 30-120 \mu \mathrm{g} / \mathrm{mL}$ & Not available & Pavlovic et al., 2017 [43] \\
\hline 33. & $\begin{array}{c}\text { Cymbopogon martinii - palmarosa } \\
\text { Rosaceae }\end{array}$ & Isolated rabbit jejunum/0.01-3 mg/mL & Inhibition of $\mathrm{Ca}^{2+}$ channels & Janbaz et al., 2014 [44] \\
\hline 34. & $\begin{array}{l}\text { Rosa indica }(\mathrm{L} .) \\
\text { Rutaceae }\end{array}$ & Isolated rabbit jejunum/0.01-1 mg/mL & Inhibition of $\mathrm{Ca}^{2+}$ channels & Rasheed et al., 2015 [45] \\
\hline 35. & Citrus aurantifolia var. acida-lime & Isolated rabbit jejunum/Not available & Not available & Spadaro et al., 2012 [46] \\
\hline 36. & $\begin{array}{c}\text { Citrus aurantium var. sinensis-sweet orange } \\
\text { Verbenaceae }\end{array}$ & Isolated rat ileum/9.7-1000 $\mu \mathrm{g} / \mathrm{mL}$ & Not available & Sanchez-Recillas et al., 2017 [47] \\
\hline 37. & Lippia alba & Isolated rat ileum $/ 7-37 \mathrm{mg} / \mathrm{mL}$ & $\begin{array}{l}\text { Reduction of calcium influx, stimulation of } \\
\text { NO production }\end{array}$ & Blanco et al., 2013 [48] \\
\hline 38. & $\begin{array}{l}\text { Lippia thymoides } \\
\text { Zingiberaceae }\end{array}$ & Isolated guinea pig ileum/11.56-48.83 $\mu \mathrm{g} / \mathrm{mL}$ & Not available & Menezes et al., 2018 [49] \\
\hline 39. & Elettaria cardamomum—cardamom & Isolated rabbit jejunum/3-10 mg/mL & Inhibition of $\mathrm{Ca}^{2+}$ channels & Gilani et al., 2008 [50] \\
\hline
\end{tabular}


The majority of the presented preclinical studies used whole essential oils, the antispasmodic effect of individual chemical constituents of essential oils being rarely investigated. Sadraei et al. [28] demonstrated antispasmodic effects not only for the essential oil from Melissa officinalis but also for citral, one of its main components. Heimes et al. [31] investigated the spasmolytic effects of menthol, a major constituent in the essential oil from Mentha $x$ piperita. De Souza et al. [33] tested the antispasmodic effect of several monoterpenes from Mentha $x$ villosa essential oil, carvone and rotundifolone being the most active compounds.

While several studies confirmed the antispasmodic effect of essential oils extracted from common vegetal species extensively used in Asia or Europe like Cananga odorata [10], Foeniculum vulgare [18] or Artemisia dracunculus [21], other studies showed significant spasmolytic effects of essential oils from less-known plant species like Xylopia langsdorffiana [12], Ferula heuffelii [17] or Hofmeisteria schaffneri [24], proving that new natural sources of bioactive molecules are constantly being discovered.

The collected data from this review confirmed other studies investigating biological effects of essential oils. Martinez-Perez et al. [51] showed that monoterpenes frequently found in essential oils are the leading class of natural molecules responsible for the antispasmodic effect, followed by flavonoids and alkaloids. De Almeida et al. [52] and Sarmento-Neto et al. [53] also showed in their studies that aromatic plants from the Lamiaceae, Apiaceae and Asteraceae families are a rich source of essential oils, highly valuable for medicinal or industrial purposes.

Also, analysis of the included studies showed that, generally, the experimental models used for the assesement of essential oil antispasmodic activity were represented by ex vivo techniques. Among these, the isolated guinea pig ileum method was preferred, being considered a precise pharmacological tool capable of investigating the antispasmodic effect of natural or synthetic compounds [54]. Other isolated organs used for the evaluation of antispasmodic effect were rabbit jejunum, rat ileum, bladder or uterus and sheep ruminal and abomasal muscles. An experimental model used in vitro cell cultures [15] and only two experiments used in vivo techniques: rabbit bladder in vivo and gastrointestinal transit test in mouse $[10,24]$. The ex vivo techniques are predominant due to their use without the limitations of drug bioavailability which may be a problematic issue for the in vivo models. Ex vivo methods are also well suited for mechanistic studies due to the diversity of contractile agents which could be used experimentally [55].

\subsection{Clinical Studies Evaluating Antispasmodic Potential of Essential Oils}

Antispasmodic effect of essential oils was investigated in several clinical studies for different situations: functional dyspepsia, irritable bowel syndrome, discomfort produced by endoscopic procedures, infantile colic or dysmenorrhea (Table 2). 
Table 2. Clinical studies evaluating antispasmodic potential of essential oils.

\begin{tabular}{|c|c|c|c|c|c|}
\hline Area of Interest & Authors & Type of Clinical Study & Number of Patients & Treatment & Results \\
\hline Functional dyspepsia & Papathanasopoulos et al., 2013 [56] & Randomized, crossover study & 13 healthy volunteers & Peppermint oil 182 mg p.o., single dose & $\begin{array}{l}\text { Decreased intragastric pressure and } \\
\text { gastric motility }\end{array}$ \\
\hline Functional dyspepsia & Inamori et al., 2007 [57] & Randomized control study & 10 healthy volunteers & Peppermint oil 0.64 mL p.o., single dose & $\begin{array}{l}\text { Enhancement of gastric emptying } \\
\text { without altering gastric } \\
\text { emptying coefficient }\end{array}$ \\
\hline Functional dyspepsia & May et al., 2000 [58] & Randomized control study & $\begin{array}{l}96 \text { patients with functional } \\
\text { dyspepsia }\end{array}$ & $\begin{array}{l}\text { Peppermint oil and caraway oil } \\
\text { combination } 90 \mathrm{mg}+50 \mathrm{mg} \text { p.o., } 4 \text { weeks }\end{array}$ & $\begin{array}{l}\text { Reduction of symptoms (pain, } \\
\text { fulness, heaviness) }\end{array}$ \\
\hline Functional dyspepsia & Madisch et al., 1999 [59] & Randomized control study & $\begin{array}{l}118 \text { patients with functional } \\
\text { dyspepsia }\end{array}$ & $\begin{array}{l}\text { Peppermint oil and caraway oil } \\
\text { combination } 90 \mathrm{mg}+50 \mathrm{mg} \text { p.o., } 4 \text { weeks }\end{array}$ & Reduction of dyspeptic symptoms \\
\hline $\begin{array}{l}\text { Irritable bowel syndrome } \\
\text { (IBS) }\end{array}$ & Cash et al., 2016 [60] & Randomized control study & 72 patients with IBS & Peppermint oil 180 mg p.o., 4 weeks & Reduction of symptoms \\
\hline IBS & Khanna et al., 2014 [61] & Meta-analysis & 9 studies with 726 patients with IBS & Peppermint oil $200 \mathrm{mg}$ & $\begin{array}{l}\text { Global improvement of IBS symptoms } \\
\text { (RR 2.23, 95\% CI 1.78-2.81) }\end{array}$ \\
\hline IBS & Merat et al., 2010 [62] & Randomized control study & 90 patients with IBS & Peppermint oil 187 mg p.o., 8 weeks & $\begin{array}{l}\text { Reduction of abdominal pain and } \\
\text { discomfort }\end{array}$ \\
\hline IBS & Cappello et al., 2007 [63] & Randomized control study & 57 patients with IBS & $\begin{array}{c}\text { Peppermint oil } \\
225 \mathrm{mg} \text { p.o., } 4 \text { weeks }\end{array}$ & Reduction of total IBS symptoms \\
\hline IBS & Pittler and Ernst 1998 [64] & Meta-analysis & 8 randomized control studies & Peppermint oil & $\begin{array}{l}\text { Reduction of IBS symptoms not } \\
\text { established beyond reasonable doubt }\end{array}$ \\
\hline IBS & Liu et al., 1997 [65] & Randomized control study & 110 patients with IBS & Peppermint oil 187 mg p.o., 4 weeks & $\begin{array}{l}\text { Improvement of pain and other IBS } \\
\text { symptoms }\end{array}$ \\
\hline Endoscopic procedures & Inoue et al., 2014 [66] & Randomized control study & 226 patients with colonosco & L-menthol applied on the mucosa & Reduction of discomfort \\
\hline Endoscopic procedures & Hiki et al., 2012 [67] & Randomized control study & 131 patients with gastric endoscopy & L-menthol applied on the mucosa & Reduction of peristalsis \\
\hline Endoscopic procedures & Yamamoto et al., 2006 [68] & Randomized, control study & $\begin{array}{l}40 \text { patients with endoscopic } \\
\text { cholangiopancreatography }\end{array}$ & Peppermint oil applied to papilla & $\begin{array}{l}\text { Non-significant reduction of duodenal } \\
\text { contractions }\end{array}$ \\
\hline Infantile colic & Bezerra Alves et al., 2012 [69] & Randomized crossover study & 30 infants & Mentha piperita liquid drops, 1 drop $/ \mathrm{kg}$ & $\begin{array}{l}\text { Decreased frequency and duration of } \\
\text { infantile colic }\end{array}$ \\
\hline Primary dysmenorrhea & Ghodsi and Asltoghiri, 2014 [70] & Randomized control study & 80 female students & Fennel capsules $180 \mathrm{mg} /$ day, 3 months & Reduction of dysmenorrhea symptoms \\
\hline
\end{tabular}


The analysis of data resulted from the presented clinical studies show that peppermint oil was the predominant essential oil used for symptomatic treatment of various conditions, the strongest evidence being available for irritable bowel syndrome (IBS). The randomized controlled studies of Cash et al. [60], Merat et al. [62] and Capello et al. [63] enrolled patients with IBS diagnosed according to Rome II or III criteria, showing that peppermint oil was superior to placebo in reducing the symptom score of irritable bowel syndrome (IBS) after oral administration for one or two months. According to other studies [58,59], peppermint and caraway essential oils are a possible treatment option for patients with functional dyspepsia, reducing epigastric discomfort and abdominal bloating over four weeks of treatment. Also, L-menthol and peppermint oil were tested for the reduction of discomfort caused by endoscopic procedures being used with good results in upper GI endoscopies, colonoscopies $[66,67]$ but also in cholangiopancreatographies [68]. The study of Bezerra Alves et al. [69] found that Mentha piperita essential oil reduced the frequency of infantile colic. In addition, Ghodsi and Asltoghiri [70] found that fennel essential oil reduced primary dysmenorrhea symptoms after a prolonged oral administration [70].

The systematic reviews of Chumpitazi et al. [71] and Shams et al. [72] pointed out that peppermint oil was safe and well-tolerated by the patients, with a minimal side effect profile. Nevertheless, clinical studies evaluating the antispasmodic potential of essential oils have some limitations. They were represented mainly by randomized crossover or control studies using small numbers of patients with an insufficient statistical significance. Only the studies of Khanna et al. [61] and Pittler and Ernst [64] were metaanalysis with superior statistical power. Therefore, additional clinical studies are necessary to ascertain the therapeutic value of antispasmodic essential oils.

\subsection{Mechanisms of Antispasmodic Effect of Essential Oils and Their Constituents}

Smooth muscles are a key element present in the internal structure of multiple abdominal organs including stomach, intestine, bladder or uterus, receiving innervation from the autonomic nervous system but also autocrine or paracrine stimuli [73]. Recently, considerable progress was made to understand in great molecular detail the complex physiology of smooth muscle contraction. Excitation-contraction coupling occurs when $\mathrm{Ca}^{2+}$ ions enter from the extracellular side into the smooth muscle cells through sarcolemma voltage-dependent calcium channels, being also released from intracellular stores via inositol 1,4,5-triphosphate receptor (IP3R) situated on endoplasmic reticulum (ER) [74]. The calcium release from ER is triggered by the binding of agonists like acetylcholine or histamine on specific G-protein coupled receptors (GPCRs) from the membrane of smooth muscle cells, which activate phospholipase-C (PLC) to generate IP3. After the intracellular concentration of calcium has increased, $\mathrm{Ca}^{2+}$ ions bind to calmodulin $(\mathrm{CaM})$ and phosphorylate the myosin light-chain kinase (MLCK) with the subsequent activation of the contractile apparatus [75].

Thus, the identification and characterization of multiple molecular targets involved in smooth muscle contraction has led to the development of a variety of drugs able to reduce excessive contractility responsible for cramps and colics of the abdominal organs. Among potential new drug candidates, essential oils have become increasingly attractive due to their complex chemical composition and multiple pharmacological mechanisms: inhibition of voltage-dependent calcium channels, modulation of potassium channels, antagonism of cholinergic receptors, and modulation of intracellular cyclic adenosine monophosphate (cAMP) (Figure 1). Although some details of the antispasmodic effect of essential oils and their constituents have been explained, further research is needed to better understand their mechanism of action at cellular and molecular levels. 


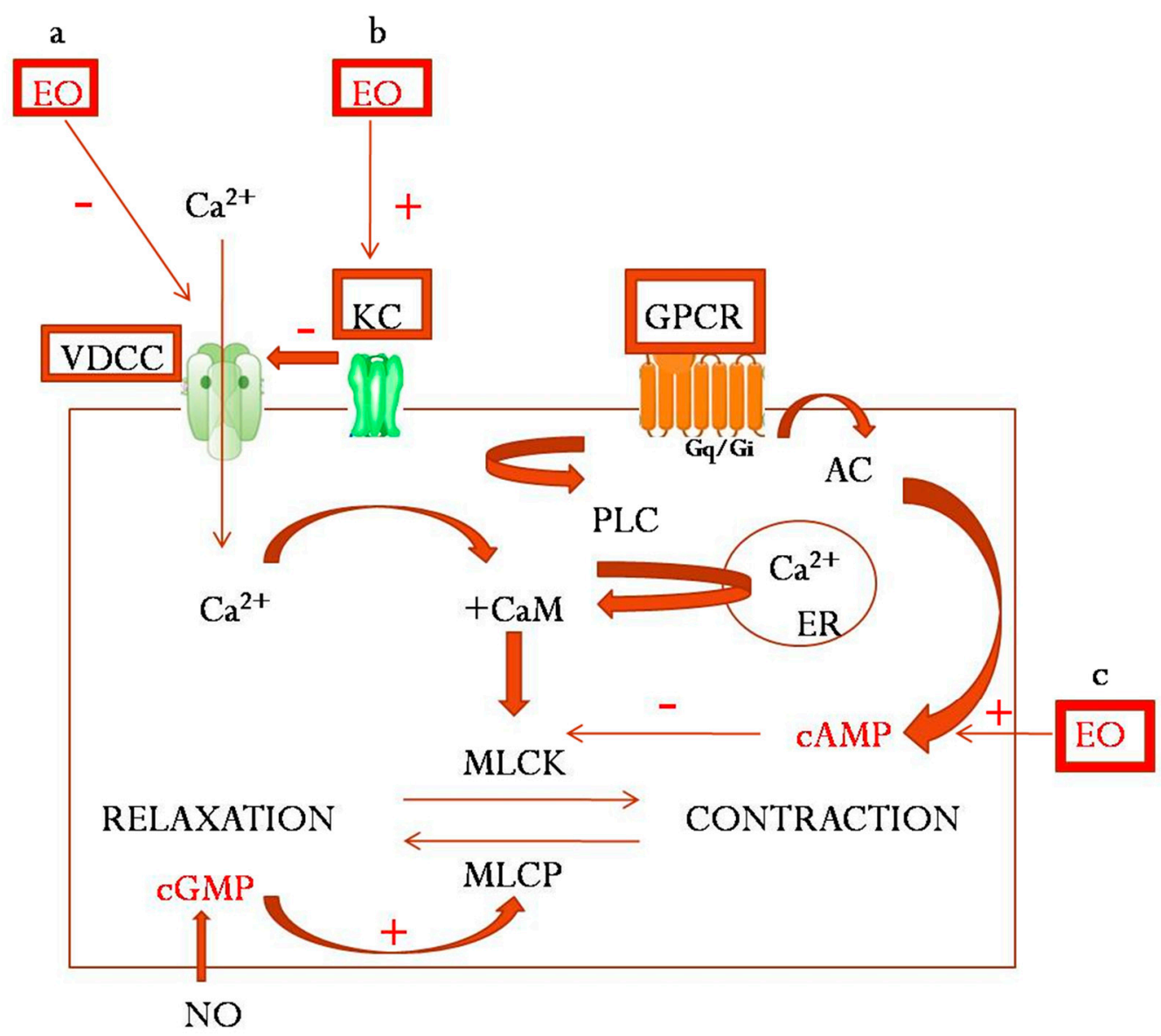

Figure 1. Main mechanisms of antispasmodic effect of essential oils: a. inhibition of voltage-dependent calcium channels; b. modulation of potassium channels; c. modulation of intracellular cAMP (EO-essential oil, VDCC — voltage-dependent calcium channel; KC—potasium channel, GPCR-G-protein coupled receptors, CaM-calmoduline, PLC—phospholipase C, AC-adenylyl cyclase, MLCK-myosin-light chain kinase, MLCP—myosin-light chain phosphatase, ER—endoplasmic reticulum, cGMP—cyclic guanosine monophosphate, cAMP—cyclic adenosine monophosphate, $\mathrm{NO}-$ nitric oxide).

\subsubsection{Inhibition of Voltage-Dependent Calcium Channels}

The opening of voltage-dependent calcium channels (VDCCs) is directly responsible for $\mathrm{Ca}^{2+}$ influx into the smooth muscle cells, partially triggering the contractile mechanism. Thus, inhibition of VDCCs has a good potential of relaxing smooth muscles, already used by several antispasmodic drugs like pinaverium [76]. Essential oils have been studied for their antispasmodic effect, the inhibitory effect on voltage-dependent calcium channels being the most commonly reported mechanism of action in the studies mentioned in our review (19 studies from 39). Some of these studies presented detailed mechanistic explanations of the antispasmodic effect for the non-fractioned essential oils. Makrane et al. [37] showed that organic fractions rich in essential oils from Origanum majorana showed a consistent spasmolytic effect on isolated rat and rabbit ileum not altered by atropine, L-NAME or methylene blue, and shifted to the right the concentrations-response curves for $\mathrm{CaCl}_{2}$, suggesting a calcium channel blocking effect. Rasheed et al. [45] showed in an experiment on isolated rabbit jejunum that essential oil from Rosa indica relaxed the organ, shifting the calcium curves to the right, showing a similar effect to verapamil, a phenylalkylamine derivative from the calcium channel blocker class. The study of Souza et al. [35] identified the same mechanism for the essential oil from Ocimum selloi which reduced the contraction of isolated guinea pig ileum induced by carbachol, $\mathrm{BaCl}_{2}$ and $\mathrm{K}^{+}$and shifted calcium concentration-response curves to the right. 
Other studies were focused on the individual components of the essential oils. Amato et al. showed that menthol $(0.1 \mathrm{mM}-30 \mathrm{mM})$ reduced in a concentration-dependent manner the contractility of human colon circular muscle, acting by an antagonistic effect on L-type $\mathrm{Ca}^{2+}$ channels [77]. The study of Ramos-Filho et al. [78] showed that menthol markedly inhibited contractions of wild and TRPM8 knockout mice bladder strips evoked by carbachol, $\mathrm{CaCl}_{2}$ or electric field stimulation. The effects of menthol were not influenced by previous incubation with sodium or potassium channel inhibitors or by the removal of urothelium, suggesting a blockade of calcium channels. Electrophysiological studies have shown that menthol was able to inhibit the calcium influx through the low-voltage activated $\mathrm{Ca}^{2+}$ channels but also to enhance the inactivation of high-voltage activated $\mathrm{Ca}^{2+}$ channels [79]. Another monoterpene, (-)-carvone was tested by Souza et al. [32] on guinea pig ileum in order to ascertain the mechanism of its spasmolytic effect, proving to be almost 100 times more potent than verapamil, a well-known calcium channel blocker (CCB) with a similar mode of action.Devi et al. [42] studied the antispasmodic effect of another terpene, citral, the major component of Cymbopogon citratus essential oil on rabbit ileum, the results showing a marked reduction of contractions evoked by $\mathrm{CaCl}_{2}$, similarly to verapamil.

\subsubsection{Modulation of Potassium Channels}

Potassium channels are largely distributed in human and animal tissues, having important physiological roles such as the regulation of smooth muscle tone [80]. Generally, the activation of voltage-gated potassium channels induces a hyperpolarisation of cell membrane with a subsequent de-activation of calcium channels leading to smooth muscle relaxation. Only a few studies investigated the effect of essential oils on potassium channels situated on smooth muscles of internal organs. Mehmood et al. [25] showed that a crude extract from Matricaria chamomilla L. containing sesquiterpenes (bisabolol) and flavonoids produced a significant antispasmodic effect on isolated rabbit jejunum. The effect on low $\mathrm{K}^{+}$induced contractions was completely blocked by 4 -aminopyridine, suggesting that the activation of potassium channels was responsible for smooth muscle relaxation. Khan et al. [40] showed that a crude extract from Salvia officinalis rich in essential oils (thujone, 1,8-cineole, camphor, linalool) caused a dose-dependent relaxation of isolated rabbit jejunum by an activation of $\mathrm{K}^{+}$channels.

Silva et al. [81] investigated the mechanism of smooth muscle relaxation of rotundifolone, the major constituent of Mentha x villosa essential oil. Patch-clamp recordings made in mesenteric smooth muscle cells showed that rotundifolone significantly increased $\mathrm{K}^{+}$currents, effect blocked by charybdotoxin which suggested the participation of big potassium (BK) channels.

\subsubsection{Antagonism of Cholinergic Receptors}

The parasympathetic nervous system has an important role in the regulation of gastrointestinal motility. Muscarinic receptors located directly on smooth muscle cells can trigger their contraction in response to acetylcholine, but nicotinic receptors have also been identified on the nerve cells from the enteric nervous system. Research on the effect of essential oils on cholinergic receptors from smooth muscles is extremely rare, only a few studies being published to date. Amato et al. [82] found that menthol induced relaxation of isolated mouse stomach by inhibiting nicotinic receptors from the enteric nervous system, reducing the release of acetylcholine from enteric nerves. The study of Lozon et al. [83] investigated the effects of vanilin, pulegone, eugenole, carvone, carvacrol, carveol, thymol, thymoquinone, menthone, and limonene on human nicotinic cholinergic receptors expressed in Xenopus oocytes. Carveol showed the most potent inhibition at the $\alpha 7$ subunit of the nicotinic receptor. The molecular interactions between terpenic compounds from essential oils and nicotinic cholinergic receptors were investigated by electrophysiological studies which showed that menthol caused a shortening of channel open time and a prolongation of channel closed time of human $\alpha 4 \beta 2$ nicotinic receptors [83]. 


\subsubsection{Modulation of Intracellular Cyclic Adenosine Monophosphate (cAMP)}

The main intracellular second messengers cAMP and cGMP are directly involved in smooth muscle relaxation. cAMP is generated by adenylyl cyclase mainly as a result of beta-adrenergic receptor activation. cGMP is produced by soluble guanylyl cyclase activated by nitric oxide or other mediators. Both cAMP and cGMP activate protein kinases PKA and PKG which may relax smooth muscles either by increasing the expulsion of calcium from the cell or by activation of MLC phosphatase which inhibits MLCK. The levels of cAMP and cGMP are severely reduced by the intervention of phosphodiesterases (PDE) involved in their degradation to inactive metabolites [73]. Multiple studies have investigated the effects of essential oils on the intracellular mechanisms of smooth muscle relaxation. In a study from 2018, Sandor et al. [22] studied the effects of the essential oil and extract from Chamaemelum nobile L. (roman chamomile) on isolated guinea pig ileum and rat gastrointestinal preparations. The essential oil significantly relaxed the isolated organs contracted with histamine, without any influence of a pretreatment with atropine, tetrodotoxin, propranolol or $\mathrm{N}^{\mathrm{G}}$-nitro-L-arginine, thus suggesting an intracellular mechanism of the antispasmodic effect. Zavala-Mendoza et al. [23] investigated the antispasmodic mechanism of the essential oil from Chrysactinia mexicana on isolated rabbit ileum. The effect was reduced by the preincubation with dibutyryl-cAMP but increased by forskolin, whereas chelerytrine or L-NNA did not modify the response, suggesting an involvement of cAMP in the antispasmodic mechanism of the essential oil. The study of Kim et al. [10] showed that essential oil from Cananga odorata (ylang-ylang) relaxed the isolated rat bladder muscle, the effect being reduced by N-ethylmaleimide but not by inhibitors of NO pathway, demonstrating the involvement of cAMP. Also, Lis-Balchin and Hart [27] found that essential oil from Lavandula angustifolia induced relaxation of isolated guinea-pig ileum through a rise in intracellular level of cAMP The effects of individual components from essential oils on intracelullar mechanism of antispasmodic effect were less studied. Leal-Cardoso et al. [84] found that eugenol (1-2000 microM) relaxed the isolated rat ileum precontracted with $\mathrm{KCl}$, without any influence from tetrodotoxin, L-NAME, hexamethonium or indomethacin, thus suggesting an intracellular mechanism.

\subsection{Chemical Composition of the Essential Oils with Antispasmodic Activity}

Essential oils are complex mixtures of volatile compounds with terpenoid or non-terpenoid structure that can be extracted from different parts of plants (flower, buds, seed, leaves, and fruits). Many of those compounds have been identified in essential oils and clasiffied as functionalized derivatives of alcohols, ketones or aldehydes, esters, ethers, oxydes and phenols $[85,86]$. The composition of an essential oil may vary according to the plant's environment and growing conditions, stage of development, methods of harvesting, extraction, and storage. The major constituents of an essential oil can also vary according to different chemotypes of the same plant species [85]. Although there is a tendency to correlate pharmacological properties with the presence of certain functional groups, this concept cannot be generalized. Thus, neurotoxicity cannot be reported for all ketones, even if it was reported in the case of thujone [86,87], as not all the alcohols have a sedative action, even if it was described for 1-linalool $[86,88,89]$.

Several molecules with a structure clearly linked to the antispasmodic effect have been identified by our review. According to the surveyed literature, they are classified as alcohols (menthol), phenols (eugenol) [84], esters (linalyl acetate, neryl acetate, geranyl acetate, iso-amyl angelate and tiglate), ethers (trans-anethole, methyl chavicol or estragole, methyleugenol) [90], oxides (1,8-cineole, piperitenone oxide) $[86,91,92]$ (Figure 2). However, other constituents present in low concentrations could be important for the pharmacological activity. 
Alcohols<smiles>CC1CCC(C(C)C)C(O)C1</smiles>

Phenols<smiles>C=CCc1ccc(O)c(OC)c1</smiles>

Eugenol

Oxides<smiles>CC12CCC(O1)C(C)(C)O2</smiles><smiles>CC(C)=C1CCC2(C)OC2C1=O</smiles>

1,8-cineole Piperitenone oxide

Ethers<smiles>C/C=C/c1ccc(OC)cc1</smiles>

Trans-anethole<smiles>C=CCc1ccc(OC)cc1</smiles>

Methyl chavicol<smiles>C=CCc1ccc(OC)c(OC)c1</smiles>

Methyleugenol

Esters

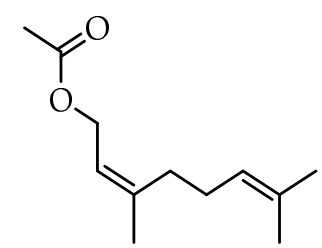

Neryl acetate<smiles>C=CC(C)(CCC=C(C)C)OC(C)=O</smiles>

Linalyl acetate<smiles>CC(=O)OC/C=C(\C)CCC=C(C)C</smiles>

Geranyl acetate<smiles>C/C=C(/C)C(=O)OCCC(C)C</smiles>

Iso-amyl angelate<smiles>CC=C(C)C(=O)OCCC(C)C</smiles>

Iso-amyl tiglate

Figure 2. Chemical structures of main constituents from antispasmodic essential oils.

Chemical composition of the antispasmodic essential oils included in our study is presented in Table 3. 
Table 3. Chemical composition of the studied antispasmodic essential oils.

\begin{tabular}{|c|c|c|c|}
\hline Plant Species & Part Use & Representative Compounds & Reference \\
\hline $\begin{array}{c}\text { Pistacia integerrima, } \\
\text { (Anacardiaceae)-zebrawood }\end{array}$ & Galls & $\begin{array}{c}\text { Hydrocarbons: monoterpenes: } \alpha \text {-pinene } 21.81 \% \text {, } \beta \text {-pinene } 16.18, \alpha \text {-terpinene } 1.37 \% \text {, } \\
\text { carene } 11.09 \% \text {, limonene } 6.35 \% \text {, } \alpha \text {-phellandrene } 15.48 \%, \beta \text {-phellandrene } 5.72 \% \text {, } \\
\text { cis- } \$ \text {-ocimene } 4.13 \% \text {, trans-1 } 3 \text {-ocimene } 4.25 \% \text {; sesquiterpenes: } \beta \text {-caryophyllene } \\
\text { 3.88-5.33\%, } \beta \text {-farnesene } 7.88 \% \text {; aromatic: } p \text {-cymene } 11.54 \% \\
\text { Alcohols: terpinen-4-ol } 11.93-28.82 \%, 4 \text {-carvomenthenol } 17.06 \%, p \text {-meth-1-en- } 8 \text {-ol } \\
\text { 43.38\%, borneol } 8.90 \% \text {, spathulenol } 6.35 \% \\
\text { Ketones: tetrahydrocarvone } 10.27 \% \\
\text { Esters: bornyl acetate } 13.99 \%\end{array}$ & [93-95] \\
\hline $\begin{array}{l}\text { Cananga odorata var. genuina, } \\
\text { (Annonaceae)-ylang ylang }\end{array}$ & Flowers & $\begin{array}{l}\text { Major components differ significantly depending on the fraction of essential oil, } \\
\text { origin of the plant material and harvesting time } \\
\text { Hydrocarbons: sesquiterpenes: B-caryophyllene } 15-26.8 \% \text {, germacrene D } 8.1-25.13 \% \text {, } \\
\delta \text {-cadinene 2-4.7\%, } \alpha \text {-humulene } 0.9-7.1 \% \text {, } \alpha \text {-farnesene } 0.3-23.75 \% \\
\text { Alcohols: linalool } 8.7-30 \% \text {, farnesol } 5.6 \% \\
\text { Ethers: p-methyl anisole } 0.39-16.5 \% \\
\text { Esters: geranyl acetate 5-10\%, farnesyl acetate } 1-7 \% \text {, methyl salicylate } 1-10 \% \text {, benzyl } \\
\text { benzoate 3.8-27.48\%, benzyl acetate 3-8\%, methyl benzoate } 1-6.05 \%\end{array}$ & {$[86,96-99]$} \\
\hline Xylopia frutescens, (Annonaceae) & Leaves & $\begin{array}{c}\text { Hydrocarbons:monoterpenes: } \alpha \text {-pinene } 2.30 \%, \beta \text {-ocimene } 8.19 \% \text {; sesquiterpenes: } \\
\text { caryophyllene } 23.91 \%, \gamma \text {-cadinene } 12.48 \%, \gamma \text {-elemene } 4.55 \%, \beta \text {-elemene } 4.31 \% \text {, } \\
\alpha \text {-selinene } 4.29 \% \text {, } \delta \text {-cadinene } 3.02 \%, \alpha \text {-humulene } 2.48 \%, \gamma \text {-muurolene } 2.23 \% \text {, } \\
\beta \text {-selinene } 2.11 \% \\
\text { Alcohols: cadin-4-en-10-ol } 5.78 \% \text {, viridiflorol } 4.83 \% \text {, sphatulenol } 3.97 \%\end{array}$ & [11] \\
\hline Xylopia langsdorfiana, (Annonaceae) & Fruits & $\begin{array}{c}\text { Hydrocarbons:monoterpenes: } \alpha \text {-pinene } 37.73 \% \text {, camphene } 11.50 \% \text {, } \beta \text {-pinene } 4.04 \% \text {, } \\
\text { limonene } 31.75 \% \text {; sesquiterpenes: sclarene } 10.38 \% \\
\text { Alcohols: } \alpha \text {-terpineol } 1.08 \% \text {, spathulenol } 1.74 \% \\
\text { Oxides: } 1,8 \text {-cineol } 1.15 \% \text {, caryophyllene oxide } 3.79 \%\end{array}$ & [100] \\
\hline Anethum graveolens, (Apiaceae)—dill & Seeds & $\begin{array}{c}\text { Hydrocarbons: monoterpenes: limonene } 1.11-83 \%, \alpha \text {-phellandrene trace-25\%, } \\
\beta \text {-phellandrene } 0-3.38 \% \\
\text { Phenols: carveol } 2 \% \text {, eugenol } \\
\text { Ketones: carvone (28-62.48\%), cis-dihydrocarvone } 0-5.87 \% \text {, trans-dihydrocarvone } \\
0-11.7 \% \text {, piperitone } 0-8.2 \% \\
\text { Ethers: apiole } 0-16.79 \% \text {, dillapiole } 0-26.8\end{array}$ & {$[86,101-108]$} \\
\hline Carum carvi, (Apiaceae)—caraway & Fruits & $\begin{array}{c}\text { Hydrocarbons: monoterpenes: limonene } 1.5-51.3 \% \text {, carvene } 30 \% \\
\text { Alcohols: cis-carveol } 5.5 \% \\
\text { Ketones: carvone } 44.5-95.9 \% \\
\text { Ethers: trans-anethole } 0-2.2 \% \text {, apiole } 12.3 \%\end{array}$ & {$[86,109-111]$} \\
\hline
\end{tabular}


Table 3. Cont.

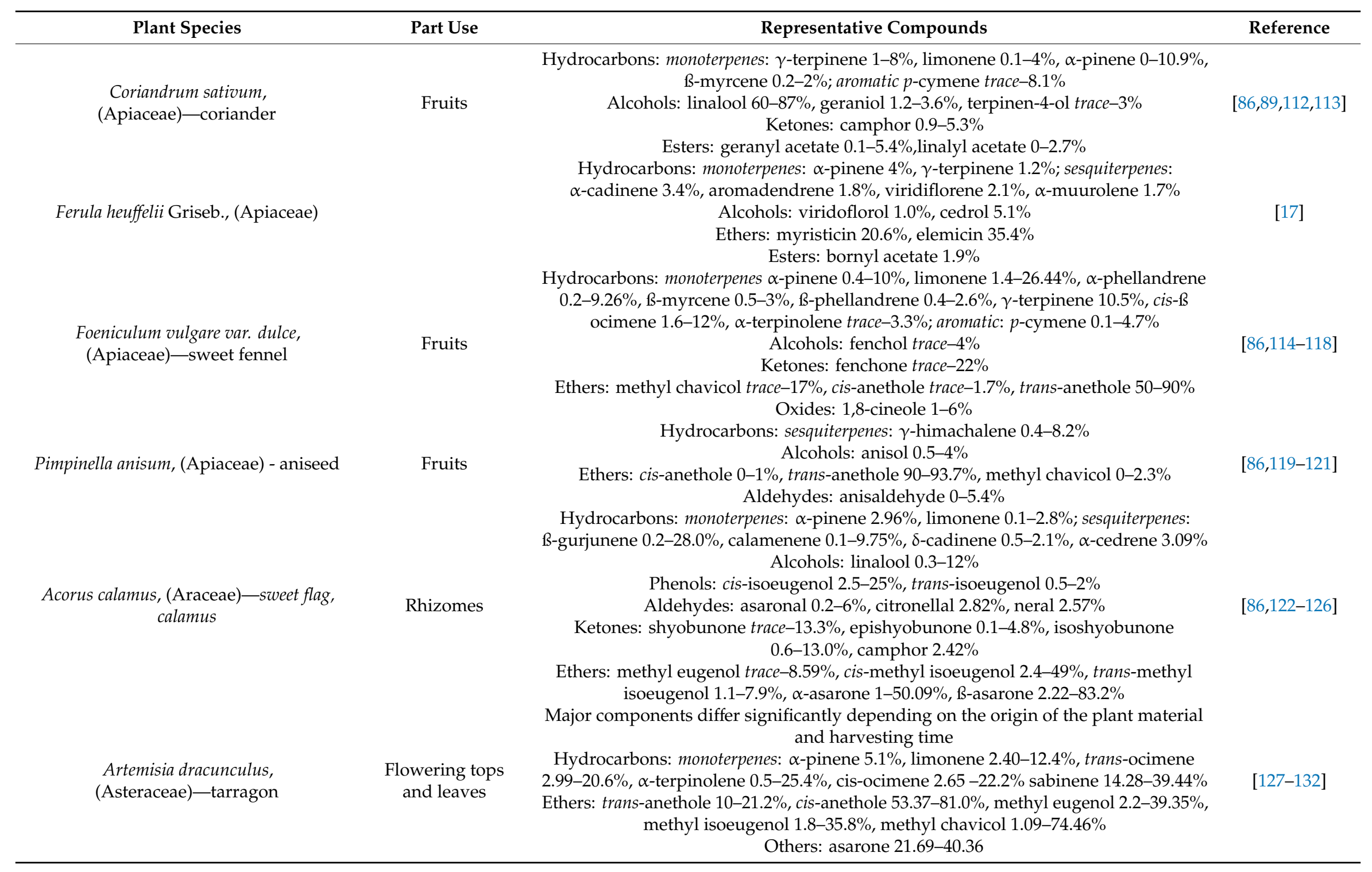


Table 3. Cont.

\begin{tabular}{|c|c|c|c|}
\hline Plant Species & Part Use & Representative Compounds & Reference \\
\hline $\begin{array}{l}\text { Chamaemelum nobile } \\
\text { (Asteraceae)_roman chamomile }\end{array}$ & Flowers & 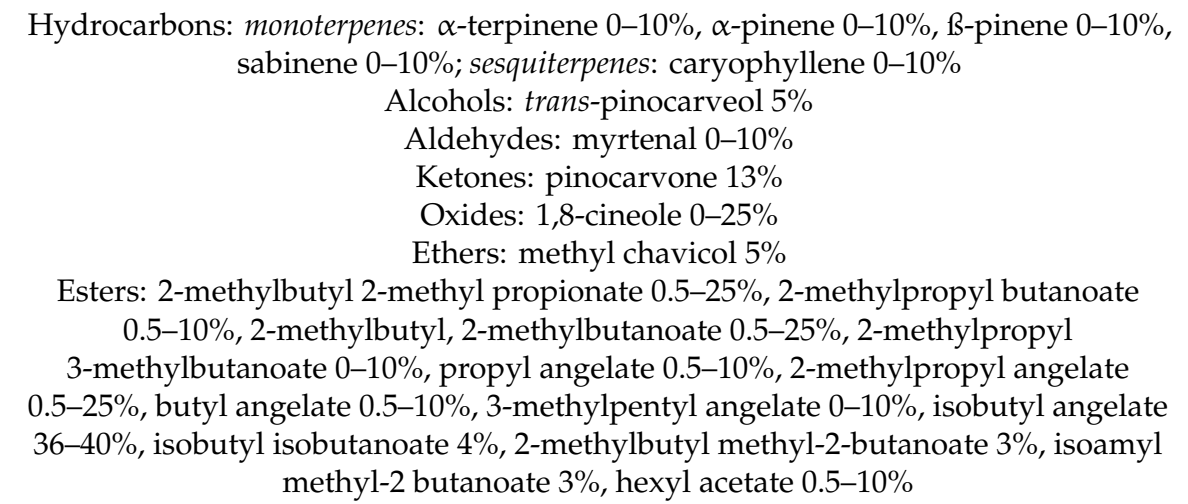 & {$[86,133-138]$} \\
\hline $\begin{array}{c}\text { Chrysactinia mexicana, } \\
\text { (Asteraceae)—damianita daisy }\end{array}$ & Leaves & $\begin{array}{c}\text { Hydrocarbons: monoterpenes: } \alpha \text {-myrcene } 1.20 \% \\
\text { Alcohols: linalool } 1.39 \% \\
\text { Ketones: } \alpha \text {-thujone } 1.17 \% \text {, piperitone } 37.74 \% \\
\text { Oxides: } 1,8 \text {-cineole } 41.3 \% \\
\text { Esters: linalyl acetate } 9.08 \%\end{array}$ & [139] \\
\hline Hofmeisteria schaffneri (Asteraceae) & Aerial parts & $\begin{array}{c}\text { Major components differ depending on the harvesting time } \\
\text { Alcohols: linalool } 0.25-1.38 \% \\
\text { Esters: thymyl isobutyrate } 1.54-3-41 \% \text {, thymyl isovalerate } 14.12-30.97 \% \text {, } \\
\text { 9-acetoxy-8,9-dehydrothymyl angelate } 2.36-5.23 \%, 8,9 \text {-epoxy-10-acetoxythymyl } \\
\text { angelate } 0.41-15 \% \\
\text { Others: hofmeisterin III } 24.12-34.85 \%\end{array}$ & [140] \\
\hline $\begin{array}{c}\text { Matricaria recutita (Asteraceae)-german } \\
\text { chamomile }\end{array}$ & Flowers & $\begin{array}{c}\text { Hydrocarbons: sesquiterpenes chamazulene } 1-35 \% \text {, trans- } \beta \text {-farnesene } 2-13 \% \text {, } \\
\text { trans- } \alpha \text {-farnesene } 27 \% \text {, } \delta \text {-cadinene } 5.2 \%, \gamma \text {-muurolene } 1.3 \%, \alpha \text {-muurolene } 3.4 \% \\
\text { Alcohols: sesquiterpenols: } \alpha \text {-bisabolol } 2-67 \% \\
\text { Oxides: } \alpha \text {-bisabol oxide A 0-55\%, } \alpha \text {-bisabolol oxide B } 4.3-19 \% \text {, bisabolone oxide A } \\
0-64 \%\end{array}$ & {$[127,133-135]$} \\
\hline $\begin{array}{l}\text { Pelargonium graveolens, } \\
\text { (Geraniaceae)-geranium }\end{array}$ & Aerial parts & $\begin{array}{c}\text { Hydrocarbons: monoterpenes: } \alpha \text {-pinene } 22.47 \% \text {; sesquiterpenes: guai-6,9-diene } 3.9-5.3 \% \text {, } \\
\beta \text {-bourbonene } 2.7-3.14 \% \text {, germacrene D 2.92-4.33\%, } \gamma \text {-cadinene } 2.38 \% \\
\text { Alcohols: citronellol 15.2-48.44\%, geraniol 6-25\%, linalool 1-13.79\%, octen-1-ol } 18.61 \% \\
\text { Aldehydes:geranial } 0-9 \% \\
\text { Ketones: menthone } 0.6-6.96 \% \text {, isomenthone } 4-8.4 \% \\
\text { Oxides: cis-rose oxide } 0.69-25 \% \text {, trans-rose oxide } 0.31-2.01 \% \text {, cariopyllene oxide } \\
2.52-3.7 \% \\
\text { Esters: citronellyl formate } 8-24.4 \% \text {, geranyl formate } 1-6.22 \% \text {, citronellyl propionate } \\
1-3 \% \text {, geranyl angelate } 1-2 \% \text {, citronellyl butanoate } 1.3 \% \text {, geranyl butanoate } 1.3 \%\end{array}$ & $\begin{array}{c}{[86,99,141-} \\
144]\end{array}$ \\
\hline
\end{tabular}


Table 3. Cont.

\begin{tabular}{|c|c|c|c|}
\hline Plant Species & Part Use & Representative Compounds & Reference \\
\hline $\begin{array}{c}\text { Lavandula angustifolia (Lamiaceae)—-true } \\
\text { lavender }\end{array}$ & Flowers & $\begin{array}{c}\text { Hydrocarbons: monoterpenes:cis-ß-ocimene } 1.3-10.9 \% \text {, trans- } \$ \text {-ocimene } 0.8-5.8 \% \text {, } \\
\text { limonene } 0.2-7 \% \text {; sesquiterpenes: } \beta \text {-caryophyllene } 2.6-7.6 \% \\
\text { Alcohols: linalool } 26-49 \% \text {, terpinen-4-ol } 0.03-6.4 \% \text {, } \alpha \text {-terpineol } 0.1-1.4 \% \text {, borneol } \\
\text { 0.8-1.4\%, lavandulol } 0.5-1.5 \% \\
\text { Oxides: } 1,8-\text {-cineole } 0.5-2.5 \% \\
\text { Esters: linalyl acetate } 35-55 \% \text {, lavandulyl acetate } 0.2-5.9 \%\end{array}$ & $\begin{array}{c}{[33,89,99,137} \\
145-148]\end{array}$ \\
\hline Melissa officinalis (Lamiaceae)-melissa & Aerial parts & $\begin{array}{c}\text { Major components differ significantly depending on the origin of the plant material } \\
\text { Hydrocarbons: sesquiterpenes: } \beta \text {-caryophyllene } 8-10 \% \text {, } \alpha \text {-copaene } 4-5 \% \\
\text { Alcohols: linalool } 0.4-2.74 \% \text {, nerol } 1.4 \% \text {, geraniol } 0.20-27.22 \% \text {, citronelol } 0-36.71 \% \\
\text { Aldehydes: neral } 3.28-31.5 \% \text {, geranial } 0-38.13 \% \text {, citronellal } 1.48-39.6 \% \\
\text { Oxides: caryophyllene oxide } 0.2-10.26 \%\end{array}$ & [149-152] \\
\hline $\begin{array}{c}\text { Mentha } \times \text { piperita } \\
\text { (Lamiaceae)-peppermint }\end{array}$ & Aerial parts & $\begin{array}{c}\text { Hydrocarbons: monoterpenes: } \alpha \text {-pinene } 0.2-2 \%, \beta-\text { pinene } 0.3-4 \% \text {, limonene } 0.6-6 \% \text {; } \\
\text { sesquiterpenes: germacrene D } 1.75-4.3 \% \\
\text { Alcohols: menthol } 25.16-48 \% \text {, neomenthol } 2-7.7 \% \text {, } \alpha \text {-terpineol } 0.1-1.9 \% \text {, cis-carveol } \\
\text { 3.35\%, terpinen- } 4-\text {-ol } 0-2.4 \% \text {, cis-thujan- } 4-\text { ol } 0.2-1.4 \% \text {, viridiflorol } 0.5-1.3 \% \text {, } \\
\text { Ketones: menthone } 16-42.97 \% \text {, isomenthone } 4-10.4 \% \text {, neomenthone } 2-3 \% \text {, piperitone } \\
\text { 0.5-1.2\%, pulegone } 4.39 \% \\
\text { Oxides: } 1 \text {, } 8 \text {-cineole } 2.15-7.4 \% \text {, transpiperitonoxide } 0.5-3.1 \% \\
\text { Esters: menthyl acetate } 1.6-10 \% \\
\text { Benzofurans: menthofuran } 0.1-5.7 \%\end{array}$ & [153-156] \\
\hline Mentha spicata (Lamiaceae)—spearmint & Aerial parts & $\begin{array}{c}\text { Hydrocarbons: monoterpenes: } \beta \text {-pinene } 0.3-2.3 \%, \beta \text {-myrcene } 1.2-5.5 \text {, limonene } 2-25 \% \text {; } \\
\text { sesquiterpenes: } \beta \text {-caryophyllene } 0.3-4.41 \%, \beta-\text { farnesene } 1.71 \% \text {, } \beta \text {-bourbonene } \\
\text { trace-2.14\%, germacrene D } 0-3.14 \% \\
\text { Alcohols: cis-carveol } 5.30 \% \text {, menthol } 0.5-2 \% \text {, terpinen- } 4 \text {-ol trace-6.1\%, } \alpha \text {-terpineol } \\
0-2.7 \% \\
\text { Ketones: carvone } 39-70 \% \text {, menthone trace-5.2\%, cis-dihydrocarvone } 3.1-21.6 \% \text {, } \\
\text { trans-dihydrocarvone } 0-21 \% \text {, isomenthone } 3.33 \% \\
\text { Oxides: } 1,8 \text {-cineole } 0.5-17.0 \% \text {, piperetenone oxide trace-79.2\% } \\
\text { Esters: dihydrocarvyl acetate } 1.2-24.8 \%, \text { cis-carvyl acetate } 0.2-5.5 \%, \text { trans-carvyl } \\
\text { acetate } 0.7-5.9 \% \text {, } \\
\text { neoisodihydrocarveol acetate } 0-21 \% \text {, menthyl acetate } 2 \% \\
\text { Benzofurans: menthofuran } 2 \%\end{array}$ & $\begin{array}{c}{[86,99,156-} \\
158]\end{array}$ \\
\hline $\begin{array}{c}\text { Mentha } x \text { vilosa } \\
\text { Huds.(Lamiaceae)-mojito mint }\end{array}$ & Aerial parts & $\begin{array}{c}\text { Hydrocarbons: monoterpenes:B-pinene } 1.42-4.04 \% \text {, myrcene } 3.10-3.66 \% \text {, limonene } \\
\text { 2.38-8.75\%; sesquiterpenes: } \beta \text {-caryophyllene } 2.82-5.16 \%, \delta \text {-cardinene } 9.69 \% \text {, } \\
\gamma \text {-muurolene } 2.18-16.02 \% \text {, germacrene-D } 3.81 \% \\
\text { Oxides: } 1,8 \text {-cineole } 1.58-3.93 \% \text {, piperitenone oxide } 58.74-79.03 \% \text {, cariophyllene oxide } \\
2.82 \%\end{array}$ & $\begin{array}{l}{[33,91,159-} \\
161]\end{array}$ \\
\hline
\end{tabular}


Table 3. Cont.

\begin{tabular}{|c|c|c|c|}
\hline Plant Species & Part Use & Representative Compounds & Reference \\
\hline Ocimum basilicum (Lamiaceae)_basil & Aerial parts & $\begin{array}{c}\text { Hydrocarbons: sesquiterpenes: } 1 \text {-caryophyllene } 2-3 \% \\
\text { Alcohols: linalool } 40-55 \%, \alpha \text {-fenchyl alcohol 3-12\%, terpinen-4-ol } 1.6 \%, \alpha \text {-terpineol } \\
2 \% \\
\text { Phenols: eugenol 1-19\%, iso-eugenol } 2 \% \\
\text { Oxides: } 1,8-\text { cineole } 2-8 \% \\
\text { Ethers: methyl chavicol 3-31\%, methyl eugenol 1-9\% } \\
\text { Esters: methyl cinnamate } 0.1-7 \%\end{array}$ & {$[86,162]$} \\
\hline $\begin{array}{c}\text { Ocimum selloi (Lamiaceae) — green } \\
\text { pepper basil }\end{array}$ & Aerial parts & $\begin{array}{c}\text { Hydrocarbons: sesquiterpenes:ß-caryophyllene } 2.2-3 \% \text {, germacrene D 0-3.14\% } \\
\text { Alcohols: linalool 20.6\%, spathulenol 1.3\% } \\
\text { Ethers: trans-anethole } 45.42 \% \text {, cis-anethole 3.95\%, methyl chavicol 24.14-93.2\%, } \\
\text { methyl eugenol } 2.2-39.35 \%\end{array}$ & {$[35,162-164]$} \\
\hline $\begin{array}{c}\text { Ocimum gratissimum } \\
\text { (Lamiaceae)-african basil }\end{array}$ & Aerial parts & $\begin{array}{c}\text { Hydrocarbons: monoterpenes: } \beta \text {-pinene } 6.2 \% \text {, cis-ocimene } 13.9-23.97 \% \text {, trans-ocimene } \\
\text { 19.60-48.28\%, } \gamma \text {-terpinene } 0.20-28.10 \% \text {, limonene } 11.40 \% \text {; sesquiterpenes: } \\
\text { B-caryophyllene } 2.7-3.06 \% \text {, } \beta \text {-phellandrene }(21.10) \text {, germacrene D } 7.30-10.36 \% \text {, } \\
\alpha \text {-trans-bergamotene } 4.1 \%, \gamma \text { - muurolene } 9.32-11.6 \% \text {; aromatic: } p \text {-cymene } 4.40-19.90 \% \\
\text { Phenols: eugenol } 10.70-74.80 \% \text {, thymol } 13.10-46.60 \% \\
\text { Oxides: } 1,8 \text {-cineole } 0-54.94 \%\end{array}$ & $\begin{array}{c}{[36,162,165,} \\
166]\end{array}$ \\
\hline $\begin{array}{c}\text { Origanum majorana, (Lamiaceae)—sweet } \\
\text { marjoram }\end{array}$ & Aerial parts & 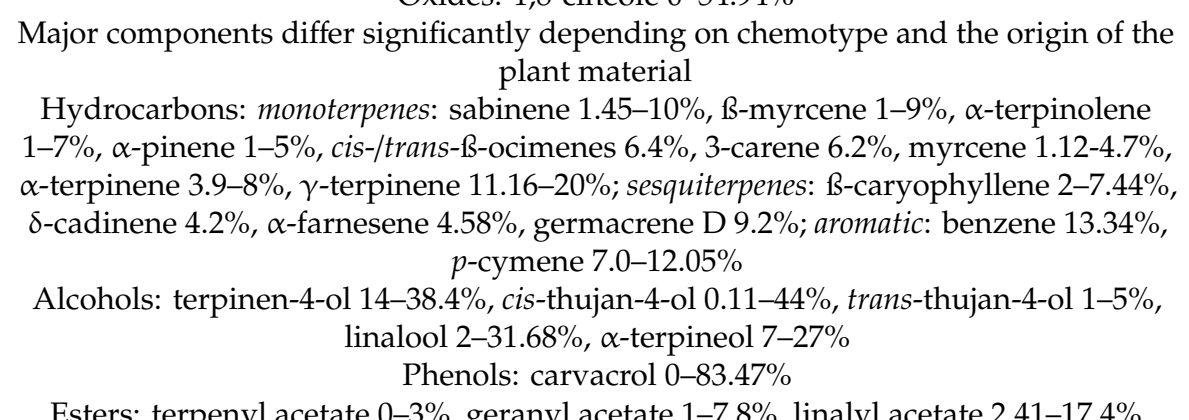 & {$[86,167-171]$} \\
\hline $\begin{array}{l}\text { Plectranthus barbatus synonym Coleus } \\
\text { forskohlii, (Lamiaceae)_Iindian coleus }\end{array}$ & Aerial parts & $\begin{array}{c}\text { Hydrocarbons: monoterpenes: } \alpha \text {-pinene } 12-67 \%, \beta \text {-pinene } 0.1-22 \%, \beta \text {-myrcene } 1.8 \% \text {, } \\
\text { cis- } \beta \text {-ocimene } 1.9 \% \text {, trans- } \beta \text {-ocimene } 1.2 \% \text {; sesquiterpenes: } \beta \text {-caryophyllene } 7-12 \% \text {, } \\
\text {-copaene } 8.9 \%, \beta \text {-cubebene } 3.7 \% \\
\text { Alcohols: oct-1-en-3-ol traces- } 28 \% \\
\text { Phenols: thymol } 15.3 \% \text {, carvacrol } 12.1 \% \text {, eugenol } 25.1 \%\end{array}$ & {$[38,172-174]$} \\
\hline
\end{tabular}


Table 3. Cont

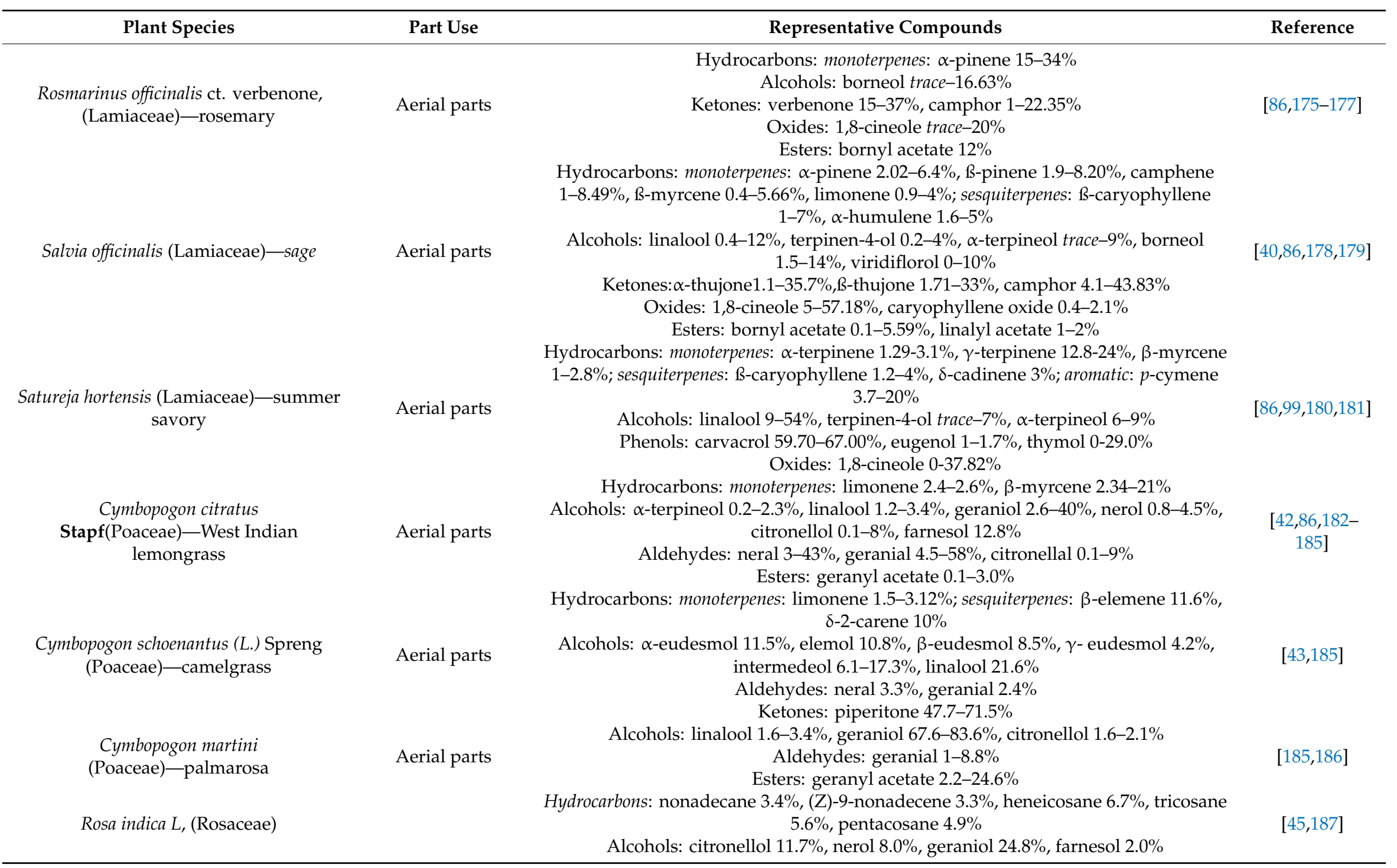


Table 3. Cont

\begin{tabular}{|c|c|c|c|}
\hline Plant Species & Part Use & Representative Compounds & Reference \\
\hline $\begin{array}{l}\text { Citrus aurantifolia/Citrus medica var. acida } \\
\text { (Rutaceae)-lime }\end{array}$ & Pericarps & $\begin{array}{c}\text { Hydrocarbons: monoterpenes: limonene } 36-60 \%, \gamma \text {-terpinene } 6-17.6 \%, \alpha \text {-pinene } \\
0.2-5.03 \% \text {, } \beta \text {-pinene } 4.9-19.5 \% \text {, } \beta \text {-myrcene } 1-2.6 \% \text {; sesquiterpenes: } \beta \text {-caryophyllene } \\
\text { 1.3-3.4\%, } \alpha \text {-bisabolene } 2.3 \% \text {; aromatic } p \text {-cymene } 0.1-6.8 \% \\
\text { Alcohols: linalool } 1.4-16.9 \%, \alpha \text {-terpineol } 13-23 \% \\
\text { Aldehydes: citronellal } 0-5.3 \% \text {, neral } 0.7-4.7 \% \text {, geranial } 1.81-6.4 \% \\
\text { Esters: linalyl acetate } 26-27 \%\end{array}$ & $\begin{array}{c}{[46,86,99,188,} \\
189]\end{array}$ \\
\hline $\begin{array}{l}\text { Citrus aurantium var. sinensis } \\
\text { (Rutaceae)—sweet orange }\end{array}$ & Pericarps & $\begin{array}{c}\text { Hydrocarbons: limonene } 87.9-96.8 \% \text {, ß-myrcene } 1.37-2.5 \% \text {, } 1 \text {-phellandrene } 0-1.5 \% \\
\text { Alcohols: linalool } 0.5-2.4 \% \\
\text { Ketones: carvone } 1.8 \%\end{array}$ & {$[86,99,190,191]$} \\
\hline Lippia alba, (Verbenaceae) & Leaves & $\begin{array}{c}\text { The plant presents a great morphological and chemical variability with a } \\
\text { predominance of monoterpene type compounds such as citral, } \beta \text {-myrcene, limonene } \\
\text { and carvone, based on which several chemotyps have been described. } \\
\text { Hydrocarbons: monoterpenes: limonene } 8.2-15.7 \%, \gamma \text {-terpinene } 4.09 \% \text {, myrcene } \\
\text { 6.6-8.3\%; sesquiterpenes: } \beta \text {-caryophyllene } 2.7-3.07 \% \text {, germacrene D } 3.0-5.47 \% \\
\text { Alcohols: } \beta \text {-elemol } 5.37 \% \text {, nerol } 2.2 \% \text {, geraniol } 2.9 \% \text {, linalool } 0.8-64.2 \% \\
\text { Aldehydes: geranial } 6.5-50.94 \% \text {, neral } 11.5-33.32 \% \\
\text { Ketones: carvone } 16.7-33.7 \% \\
\text { Oxides: cariopyllene oxide } 0-2.64 \%\end{array}$ & [48,192-195] \\
\hline Lippia thymoides, (Verbenaceae) & Leaves & $\begin{array}{l}\text { Hydrocarbons: monoterpenes: } \alpha \text {-pinene } 0.94-2.38 \% \text {, camphene } 2.64-5.66 \% \text {, limonene } \\
1.67-3.75 \% \text {,; sesquiterpenes: copaene } 2.42-3.38 \%, \beta \text {-caryophyllene } 5.32-26.27 \% \text {, } \\
\alpha \text {-caryophyllene } 3.06-5.48 \% \text {, germacrene D } 4.72-6.18 \% \\
\text { Alcohols: borneol } 4.45-7.36 \% \\
\text { Phenols: thymol trace- } 66.33 \% \\
\text { Ketones: camphor } 3.22-8.61 \% \\
\text { Oxides: cariopyllene oxide } 0.9-2.7 \% \\
\text { Ethers: } 1,8-\text { cineole } 1.86-4.5 \% \\
\text { Esters: thymol acetate } 0-7.49 \%\end{array}$ & {$[49,196,197]$} \\
\hline $\begin{array}{c}\text { Elettaria cardamomum, } \\
\text { (Zingiberaceae)—cardomom }\end{array}$ & Fruits & $\begin{array}{c}\text { Hydrocarbons: monoterpenes: limonene } 1.7-14 \% \text {, sabinene } 1.3-5 \% \text {, } 1 \text {-myrcene } 0.2-2.2 \% \\
\text { Alcohols: linalool } 0.4-6.9 \% \text {, terpinen- } 4 \text {-ol } 0.1-3.2 \% \text {, } \alpha \text {-terpineol } 0.8-5.25 \% \text {, geraniol } \\
\text { 0.2-1.6\%, trans-nerolidol } 0.1-2.7 \% \text {, cis-nerolidol } 0.2-1.6 \% \\
\text { Oxides: } 1,8 \text {-cineole } 15.13-50 \% \\
\text { Esters: } \alpha \text {-terpinyl acetate } 29-56.87 \% \text {, linalyl acetate } 0.2-7.7 \%\end{array}$ & [86,198-202] \\
\hline
\end{tabular}




\section{Conclusions}

This review identified 39 plant species bearing essential oils with antispasmodic effect demonstrated in preclinical studies. The main mechanisms of the antispasmodic effect were represented by inhibition of voltage-dependent calcium channels, modulation of potassium channels and modulation of intracellular cAMP. Certain individual components identified in the chemical composition of the essential oils studied could become promising new drug candidates but future clinical studies are needed in order to ascertain their therapeutical value.

Author Contributions: Conceptualization, S.C.H. and O.V.; Methodology, O.V.; Software, L.R.; Validation, S.C.H., O.V. and C.M.; Formal Analysis, L.R.; Investigation, S.C.H. and O.V.; Resources, S.C.H. and O.V.; Data Curation, L.R. and C.A.I.; Writing-Original Draft Preparation, S.C.H. and O.V.; Writing-Review andEditing, S.C.H., L.R. and O.V.; Visualization, L.F.; Supervision, C.M., C.A.I. and L.F.; Project Administration, L.F.; Funding Acquisition, L.F.

Funding: This research received no external funding.

Conflicts of Interest: The authors declare no conflict of interest.

\section{References}

1. Hicks, G.A. Irritable Bowel Syndrome. In Comprehensive Medicinal Chemistry; Taylor, J.B., Triggle, D.J., Eds.; Elsevier Science: London, UK, 2007; pp. 643-670. ISBN 978-0-08-045044-5.

2. Annaházi, A.; Róka, R.; Rosztóczy, A.; Wittmann, T. Role of antispasmodics in the treatment of irritable bowel syndrome. World J. Gastroenterol. 2014, 20, 6031-6043. [CrossRef] [PubMed]

3. Baiu, I.; Hawn, M.T. Gallstones and Biliary Colic. JAMA 2018, 320, 1612. [CrossRef]

4. Sanagapalli, S.; Agnihotri, K.; Leong, R.; Corte, C.J. Antispasmodic drugs in colonoscopy: A review of their pharmacology, safety and efficacy in improving polyp detection and related outcomes. Therap. Adv. Gastroenterol. 2017, 10, 101-113. [CrossRef]

5. Can Baser, H.K.; Buchbauer, G. Handbook of Essential Oils: Science, Technology and Applications; CRC Press: Boca Raton, FL, USA, 2010; pp. 3-39. ISBN 9781466590465.

6. Yarnell, E.; Abascal, K. Spasmolytic botanicals. Altern. Complement. Ther. 2011, 17, 169-172. [CrossRef]

7. Sharifi-Rad, J.; Sureda, A.; Tenore, G.C.; Daglia, M.; Sharifi-Rad, M.; Valussi, M.; Tundis, R.; Sharifi-Rad, M.; Loizzo, M.R.; Oluwaseun Ademiluyi, A.; et al. Biological activities of essential oils: From plant chemoecology to traditional healing systems. Molecules 2017, 22, 70. [CrossRef]

8. De Araújo, D.A.M.; Freitas, C.; Cruz, J.S. Essential oils components as a new path to understand ion channel molecular pharmacology. Life Sci. 2011, 89, 540-544. [CrossRef] [PubMed]

9. Shirole, R.L.; Shirole, N.L.; Saraf, M.N. In vitro relaxant and spasmolytic effects of essential oil of Pistacia integerrima Stewart ex Brandis Galls. J. Ethnopharmacol. 2015, 168, 61-65. [CrossRef]

10. Kim, H.J.; Yang, H.M.; Kim, D.H.; Kim, H.G.; Jang, W.C.; Lee, Y. Effects of ylang-ylang essential oil on the relaxation of rat bladder muscle in vitro and white rabbit bladder in vivo. J. Korean Med. Sci. 2003, 18, 409-414. [CrossRef]

11. de Souza, I.L.L.; de Carvalho Correia, A.C.; da Cunha Araujo, L.C.; Vasconcelos, L.H.C.; Silva, M.D.C.C.; de Oliveira Costa, V.C.; Tavares, J.F.; Paredes-Gamero, E.J.; de Andrade Cavalcante, F.; da Silva, B.A. Essential oil from Xylopia frutescens Aubl. reduces cytosolic calcium levels on guinea pig ileum: Mechanism underlying its spasmolytic potential. BMC Complement. Altern. Med. 2015, 15, 327. [CrossRef] [PubMed]

12. de C. Correia, A.C.; Ferreira, T.F.; Martins, I.R.R.; Macêdo, C.L.; de S. Monteiro, F.; Costa, V.C.O.; Tavares, J.F.; Silva, M.S.; Paredes-Gamero, E.J.; Buri, M.V.; et al. Essential oil from the leaves of Xylopia langsdorffiana (Annonaceae) as a possible spasmolytic agent. Nat. Prod. Res. 2015, 29, 980-984. [CrossRef]

13. Gharib Naseri, M.K.; Heidari, A. Antispasmodic effect of Anethum graveolens fruit extract on rat ileum. Int. J. Pharmacol. 2007, 3, 260-264. [CrossRef]

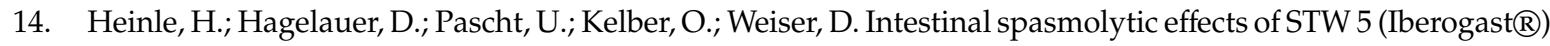
and its components. Phytomedicine 2006, 13, 75-79. [CrossRef] [PubMed] 
15. Al-Essa, M.K.; Shafagoj, Y.A.; Mohammed, F.I.; Afifi, F.U. Relaxant effect of ethanol extract of Carum carvi on dispersed intestinal smooth muscle cells of the guinea pig. Pharm. Biol. 2010, 48, 76-80. [CrossRef] [PubMed]

16. Jabeen, Q.; Bashir, S.; Lyoussi, B.; Gilani, A.H. Coriander fruit exhibits gut modulatory, blood pressure lowering and diuretic activities. J. Ethnopharmacol. 2009, 122, 123-130. [CrossRef]

17. Pavlović, I.; Petrović, S.; Radenković, M.; Milenković, M.; Couladis, M.; Branković, S.; Drobac, M.P.; Niketić, M. Composition, antimicrobial, antiradical and spasmolytic activity of Ferula heuffelii Griseb. ex Heuffel (Apiaceae) essential oil. Food Chem. 2012, 130, 310-315. [CrossRef]

18. Ostad, S.N.; Soodi, M.; Shariffzadeh, M.; Khorshidi, N.; Marzban, H. The effect of fennel essential oil on uterine contraction as a model for dysmenorrhea, pharmacology and toxicology study. J. Ethnopharmacol. 2001, 76, 299-304. [CrossRef]

19. Tirapelli, C.R.; de Andrade, C.R.; Cassano, A.O.; De Souza, F.A.; Ambrosio, S.R.; da Costa, F.B.; de Oliveira, A.M. Antispasmodic and relaxant effects of the hidroalcoholic extract of Pimpinella anisum (Apiaceae) on rat anococcygeus smooth muscle. J. Ethnopharmacol. 2007, 110, 23-29. [CrossRef]

20. Gilani, A.U.; Shah, A.J.; Ahmad, M.; Shaheen, F. Antispasmodic effect of Acorus calamus Linn. is mediated through calcium channel blockade. Phytother. Res. 2006, 20, 1080-1084. [CrossRef]

21. Jalilzadeh-Amin, G.; Maham, M.; Dalir-Naghadeh, B.; Kheiri, F. In vitro effects of Artemisia dracunculus essential oil on ruminal and abomasal smooth muscle in sheep. Comp. Clin. Path. 2012, 21, 673-680. [CrossRef]

22. Sándor, Z.; Mottaghipisheh, J.; Veres, K.; Hohmann, J.; Bencsik, T.; Horváth, A.; Kelemen, D.; Papp, R.; Barthó, L.; Csupor, D. Evidence supports tradition: The in vitro effects of Roman Chamomile on smooth muscles. Front. Pharmacol. 2018, 9, 1-11. [CrossRef]

23. Zavala-Mendoza, D.; Grasa, L.; Zavala-Sánchez, M.Á.; Pérez-Gutiérrez, S.; Murillo, M.D. Antispasmodic effects and action mechanism of essential oil of Chrysactinia mexicana A. Gray on rabbit ileum. Molecules 2016, 21, 783. [CrossRef] [PubMed]

24. Perez-Vasquez, A.; Angeles-Lopez, G.; Rivero-Cruz, I.; Flores-Bocanegra, L.; Linares, E.; Bye, R.; Mata, R. Spasmolytic action of preparations and compounds from Hofmeisteria schaffneri. Nat. Prod. Commun. 2017, 12, 475-476. [CrossRef]

25. Mehmood, M.H.; Munir, S.; Khalid, U.A.; Asrar, M.; Gilani, A.H. Antidiarrhoeal, antisecretory and antispasmodic activities of Matricaria chamomilla are mediated predominantly through $\mathrm{K}+$-channels activation. BMC Complement. Altern. Med. 2015, 15, 75. [CrossRef]

26. Lis-Balchin, M.; Hart, S.; Roth, G. The spasmolytic activity of the essential oils of scented Pelargoniums (Geraniaceae). Phytother. Res. 1997, 11, 583-584. [CrossRef]

27. Lis-Balchin, M.; Hart, S. Studies on the mode of action of the essential oil of Lavender (Lavandula angustifolia P. Miller). Phytother. Res. 1999, 13, 540-542. [CrossRef]

28. Sadraei, H.; Ghannadi, A.; Malekshahi, K. Relaxant effect of essential oil of Melissa officinalis and citral on rat ileum contractions. Fitoterapia 2003, 74, 445-452. [CrossRef]

29. Aubert, P.; Guinobert, I.; Guilbot, A.; Dubourdeaux, M.; Neunlist, M. Antispasmodic and spamolytic activity of Melissa officinalis EPS upon mice gastrointestinal tract: An ex vivo pilot study. Planta Med. 2016, 82, S1-S381.

30. Grigoleit, H.G.; Grigoleit, P. Pharmacology and preclinical pharmacokinetics of peppermint oil. Phytomedicine 2005, 12, 612-616. [CrossRef] [PubMed]

31. Heimes, K.; Hauk, F.; Verspohl, E.J. Mode of action of peppermint oil and (-)-menthol with respect to 5-HT 3 receptor subtypes: Binding studies, cation uptake by receptor channels and contraction of isolated rat ileum. Phytother. Res. 2011, 25, 702-708. [CrossRef]

32. Souza, F.V.M.; Da Rocha, M.B.; De Souza, D.P.; Marçal, R.M. Carvone: Antispasmodic effect and mode of action. Fitoterapia 2013, 85, 20-24. [CrossRef]

33. De Sousa, D.P.; Júnior, G.A.S.; Andrade, L.N.; Calasans, F.R.; Nunes, X.P.; Barbosa-Filho, J.M.; Batista, J.S. Structure and Spasmolytic Activity Relationships of Monoterpene Analogues Found in Many Aromatic Plants. Z. Naturforsch. C 2008, 63, 808-812. [CrossRef] 
34. Janbaz, K.H.; Hamid, I.; Gilani, A.-H.; Qadir, M.I. Spasmolytic, Bronchodilator and Vasodilator Activities of Aqueous-methanolic Extract of Ocimum basilicum. Int. J. Agric. Biol. 2014, 16, 321-327.

35. Souza, S.D.F.; Franca, C.S.L.; Niculau, E.S.; Costa, L.C.B.; Pinto, J.E.B.; Alves, P.B.; Marçal, R.M. Antispasmodic effect of Ocimum selloi essential oil on the guinea-pig ileum. Nat. Prod. Res. 2015, 29, 2125-2128. [CrossRef] [PubMed]

36. Madeira, S.V.F.; Matos, F.J.A.; Leal-Cardoso, J.H.; Criddle, D.N. Relaxant effects of the essential oil of Ocimum gratissimum on isolated ileum of the guinea pig. J. Ethnopharmacol. 2002, 81, 1-4. [CrossRef]

37. Makrane, H.; Aziz, M.; Mekhfi, H.; Ziyyat, A.; Bnouham, M.; Abdelkhaleq, L.; Gressier, B.; Eto, B. Antispasmodic and Myorelaxant Activity of Organic Fractions from Origanum majorana L. on Intestinal Smooth Muscle of Rodents. European J. Med. Plants 2018, 23, 1-11. [CrossRef]

38. Câmara, C.C.; Nascimento, N.R.F.; Macêdo-Filho, C.L.; Almeida, F.B.S.; Fonteles, M.C. Antispasmodic Effect of the Essential Oil of Plectranthus barbatus and some Major Constituents on the Guinea-Pig Ileum. Planta Med. 2003, 69, 1080-1085. [CrossRef] [PubMed]

39. Ventura-Martínez, R.; Rivero-Osorno, O.; Gómez, C.; González-Trujano, M.E. Spasmolytic activity of Rosmarinus officinalis L. involves calcium channels in the guinea pig ileum. J. Ethnopharmacol. 2011, 137, 1528-1532. [CrossRef]

40. Khan, A.; Najeeb-ur-Rehman; Alkharfy, K.M.; Gilani, A.H. Antidiarrheal and antispasmodic activities of Salvia officinalis are mediated through activation of K + channels. Bangladesh J. Pharmacol. 2011, 6, 111-116. [CrossRef]

41. Hajhashemi, V.; Sadraei, H.; Ghannadi, A.R.; Mohseni, M. Antispasmodic and anti-diarrhoeal effect of Satureja hortensis L. essential oil. J. Ethnopharmacol. 2000, 71, 187-192. [CrossRef]

42. Devi, R.C.; Sim, S.M.; Ismail, R. Spasmolytic effect of citral and extracts of Cymbopogon citratus on isolated rabbit ileum. J. Smooth Muscle Res. 2011, 47, 143-156. [CrossRef] [PubMed]

43. Pavlovic, I.; Omar, E.; Drobac, M.; Radenkovic, M.; Brankovic, S.; Kovacevic, N. Chemical composition and spasmolytic activity of Cymbopogon schoenanthus (L.) Spreng. (Poaceae) essential oil from Sudan. Arch. Biol. Sci. 2017, 69, 409-415. [CrossRef]

44. Janbaz, K.H.; Qayyum, A.; Saqib, F.; Imran, I.; Zia-Ul-Haq, M.; De Feo, V. Bronchodilator, vasodilator and spasmolytic activities of Cymbopogon martinii. J. Physiol. Pharmacol. 2014, 65, 859-866. [PubMed]

45. Rasheed, H.M.; Khan, T.; Wahid, F.; Khan, R.; Shah, A.J. Chemical Composition and Vasorelaxant and Antispasmodic Effects of Essential Oil from Rosa indica L. Petals. Evid. Based Complement. Alternat. Med. 2015, 2015, 279247. [CrossRef] [PubMed]

46. Spadaro, F.; Costa, R.; Circosta, C.; Occhiuto, F. Volatile composition and biological activity of key lime Citrus aurantifolia essential oil. Nat. Prod. Commun. 2012, 7, 1523-1526. [CrossRef]

47. Sánchez-Recillas, A.; Arroyo-Herrera, A.L.; Araujo-León, J.A.; Hernández Núñez, E.; Ortiz Andrade, R. Spasmolytic and Antibacterial Activity of Two Citrus sinensis Osbeck Varieties Cultivated in Mexico. Evid. Based Complement. Alternat. Med. 2017, 2017, 3960837. [CrossRef] [PubMed]

48. Blanco, M.A.; Colareda, G.A.; Van Baren, C.; Bandoni, A.L.; Ringuelet, J.; Consolini, A.E. Antispasmodic effects and composition of the essential oils from two South American chemotypes of Lippia alba. J. Ethnopharmacol. 2013, 149, 803-809. [CrossRef] [PubMed]

49. Menezes, P.M.N.; de Oliveira, H.R.; Brito, M.C.; de Paiva, G.O.; Ribeiro, L.A.D.A.; Lucchese, A.M.; Silva, F.S. Spasmolytic and antidiarrheal activities of Lippia thymoides (Verbenaceae) essential oil. Nat. Prod. Res. 2018, 1-3. [CrossRef] [PubMed]

50. Gilani, A.H.; Jabeen, Q.; Khan, A.U.; Shah, A.J. Gut modulatory, blood pressure lowering, diuretic and sedative activities of cardamom. J. Ethnopharmacol. 2008, 115, 463-472. [CrossRef] [PubMed]

51. Martínez-Pérez, E.F.; Juárez, Z.N.; Hernández, L.R.; Bach, H. Natural Antispasmodics: Source, Stereochemical Configuration, and Biological Activity. Biomed Res. Int. 2018, 3819714, 1-32. [CrossRef]

52. de Almeida, N.R.; de Fátima Agra, M.; Negromonte Souto Maior, F.; De Sousa, D.P. Essential Oils and Their Constituents: Anticonvulsant Activity. Molecules 2011, 16, 2726-2742. [CrossRef]

53. Sarmento-Neto, J.F.; Do Nascimento, L.G.; Felipe, C.F.B.; De Sousa, D.P. Analgesic potential of essential oils. Molecules 2016, 21, 20. [CrossRef]

54. Ielciu, I.; Voştinaru, O.; Oniga, S.; Mogoşan, C.; Vlase, L.; Parnau, A.; Araniciu, C.; Palage, M. Synthesis and effects of some new 2-aryl-thiazole ammonium salts on isolated ileum motility. Dig. J. Nanomater. Bios. 2013, 8, 1089-1099. 
55. Mukai, T.; Yamaguchi, E.; Goto, J.; Takagi, K. Smooth muscle relaxing drugs and guinea pig ileum. Jpn. J. Pharmacol. 1981, 31, 147-157. [CrossRef]

56. Papathanasopoulos, A.; Rotondo, A.; Janssen, P.; Boesmans, W.; Farré, R.; Vanden Berghe, P.; Tack, J. Effect of acute peppermint oil administration on gastric sensorimotor function and nutrient tolerance in health. Neurogastroenterol. Motil. 2013, 25, e263-e271. [CrossRef]

57. Inamori, M.; Akiyama, T.; Akimoto, K.; Fujita, K.; Takahashi, H.; Yoneda, M.; Abe, Y.; Kubota, K.; Saito, S.; Ueno, N.; et al. Early effects of peppermint oil on gastric emptying: A crossover study using a continuous real-time 13C breath test (BreathID system). J. Gastroenterol. 2007, 42, 539-542. [CrossRef]

58. May, B.; Köhler, S.; Schneider, B. Efficacy and tolerability of a fixed combination of peppermint oil and caraway oil in patients suffering from functional dyspepsia. Aliment. Pharmacol. Ther. 2000, 14, 1671-1677. [CrossRef]

59. Madisch, A.; Heydenreich, C.-J.; Wieland, V.; Hufnagel, R.; Hotz, J. Treatment of Functional Dyspepsia with a Fixed Peppermint Oil and Caraway Oil Combination Preparation as Compared to Cisapride. Arzneimittelforschung 1999, 49, 925-932. [CrossRef]

60. Cash, B.D.; Epstein, M.S.; Shah, S.M. A Novel Delivery System of Peppermint Oil Is an Effective Therapy for Irritable Bowel Syndrome Symptoms. Dig. Dis. Sci. 2016, 61, 560-571. [CrossRef]

61. Khanna, R.; MacDonald, J.K.; Levesque, B.G. Peppermint Oil for the Treatment of Irritable Bowel Syndrome. J. Clin. Gastroenterol. 2013, 48, 505-512. [CrossRef]

62. Merat, S.; Khalili, S.; Mostajabi, P.; Ghorbani, A.; Ansari, R.; Malekzadeh, R. The Effect of Enteric-Coated, Delayed-Release Peppermint Oil on Irritable Bowel Syndrome. Dig. Dis. Sci. 2010, 55, 1385-1390. [CrossRef]

63. Cappello, G.; Spezzaferro, M.; Grossi, L.; Manzoli, L.; Marzio, L. Peppermint oil (Mintoil@) in the treatment of irritable bowel syndrome: A prospective double blind placebo-controlled randomized trial. Dig. Liver Dis. 2007, 39, 530-536. [CrossRef] [PubMed]

64. Pittler, M.H.; Ernst, E. Peppermint oil for irritable bowel syndrome: A critical review and metaanalysis. Am. J. Gastroenterol. 1998, 93, 1131-1135. [CrossRef] [PubMed]

65. Liu, J.H.; Chen, G.H.; Yeh, H.Z.; Huang, C.K.; Poon, S.K. Enteric-coated peppermint-oil capsules in the treatment of irritable bowel syndrome: A prospective, randomized trial. J. Gastroenterol. 1997, 32, 765-768. [CrossRef]

66. Inoue, K.; Dohi, O.; Gen, Y.; Jo, M.; Mazaki, T.; Tokita, K.; Yoshida, N.; Okayama, T.; Kamada, K.; Katada, K.; et al. L-menthol improves adenoma detection rate during colonoscopy: A randomized trial. Endoscopy 2014, 46, 196-202. [CrossRef]

67. Hiki, N.; Kaminishi, M.; Yasuda, K.; Uedo, N.; Kobari, M.; Sakai, T.; Hiratsuka, T.; Ohno, K.; Honjo, H.; Nomura, S.; et al. Multicenter phase II randomized study evaluating dose-response of antiperistaltic effect of L-menthol sprayed onto the gastric mucosa for upper gastrointestinal endoscopy. Dig. Endosc. 2012, 24, 79-86. [CrossRef]

68. Yamamoto, N.; Nakai, Y.; Sasahira, N.; Hirano, K.; Tsujino, T.; Isayama, H.; Komatsu, Y.; Tada, M.; Yoshida, H.; Kawabe, T.; et al. Efficacy of peppermint oil as an antispasmodic during endoscopic retrograde cholangiopancreatography. J. Gastroenterol. Hepatol. 2006, 21, 1394-1398. [CrossRef] [PubMed]

69. Bezerra Alves, J.G.; de Cássia Coelho Moraes de Brito, R.; Cavalcanti, T.S. Effectiveness of Mentha piperita in the Treatment of Infantile Colic: A Crossover Study. Evid. Based Complement. Alternat. Med. 2012, 2012, 981352. [CrossRef]

70. Ghodsi, Z.; Asltoghiri, M. The Effect of Fennel on Pain Quality, Symptoms, and Menstrual Duration in Primary Dysmenorrhea. J. Pediatr. Adolesc. Gynecol. 2014, 27, 283-286. [CrossRef]

71. Chumpitazi, B.P.; Kearns, G.L.; Shulman, R.J. Review article: The physiological effects and safety of peppermint oil and its efficacy in irritable bowel syndrome and other functional disorders. Aliment. Pharmacol. Ther. 2018, 47, 738-752. [CrossRef] [PubMed]

72. Shams, R.; Copare, J.L.; Johnson, D.A. Peppermint oil: Clinical uses in the treatment of gastrointestinal diseases. JSM Gastroenterol. Hepatol. 2015, 3, 1036.

73. Kuo, I.Y.; Ehrlich, B.E. Signaling in Muscle Contraction. Cold Spring Harb. Perspect. Biol. 2015, 7, a006023. [CrossRef] [PubMed]

74. Sanders, K.M. Regulation of smooth muscle excitation and contraction. Neurogastroenterol. Motil. 2008, 20, 39-53. [CrossRef] 
75. Sanders, K.M.; Koh, S.D.; Ro, S.; Ward, S.M. Regulation of gastrointestinal motility-insights from smooth muscle biology. Nat. Rev. Gastroenterol. Hepatol. 2012, 9, 633-645. [CrossRef] [PubMed]

76. Evangelista, S. Quaternary ammonium derivatives as spasmolytics for irritable bowel syndrome. Curr. Pharm. Des. 2004, 10, 3561-3568. [CrossRef]

77. Amato, A.; Liotta, R.; Mulè, F. Effects of menthol on circular smooth muscle of human colon: Analysis of the mechanism of action. Eur. J. Pharmacol. 2014, 740, 295-301. [CrossRef]

78. Ramos-Filho, A.C.S.; Shah, A.; Augusto, T.M.; Barbosa, G.O.; Leiria, L.O.; de Carvalho, H.F.; Antunes, E.; Grant, A.D. Menthol Inhibits Detrusor Contractility Independently of TRPM8 Activation. PLoS ONE 2014, 9, e111616. [CrossRef]

79. Oz, M.; El Nebrisi, E.G.; Yang, K.-H.S.; Howarth, F.C.; Al Kury, L.T. Cellular and Molecular Targets of Menthol Actions. Front. Pharmacol. 2017, 8, 472. [CrossRef]

80. Tian, C.; Zhu, R.; Zhu, L.; Qiu, T.; Cao, Z.; Kang, T. Potassium Channels: Structures, Diseases, and Modulators. Chem. Biol. Drug Des. 2014, 83, 1-26. [CrossRef] [PubMed]

81. Silva, D.F.; Araújo, I.G.A.; Albuquerque, J.G.F.; Porto, D.L.; Dias, K.L.G.; Cavalcante, K.V.M.; Veras, R.C.; Nunes, X.P.; Barbosa-Filho, J.M.; Araújo, D.A.M.; et al. Rotundifolone-Induced Relaxation is Mediated by BKCa Channel Activation and Cav Channel Inactivation. Basic Clin. Pharmacol. Toxicol. 2011, 109, 465-475. [CrossRef]

82. Amato, A.; Serio, R.; Mulè, F. Involvement of cholinergic nicotinic receptors in the menthol-induced gastric relaxation. Eur. J. Pharmacol. 2014, 745, 129-134. [CrossRef] [PubMed]

83. Lozon, Y.; Sultan, A.; Lansdell, S.J.; Prytkova, T.; Sadek, B.; Yang, K.-H.S.; Howarth, F.C.; Millar, N.S.; Oz, M. Inhibition of human $\alpha 7$ nicotinic acetylcholine receptors by cyclic monoterpene carveol. Eur. J. Pharmacol. 2016, 776, 44-51. [CrossRef]

84. Leal-Cardoso, J.H.; Lahlou, S.; Coelho-de-Souza, A.N.; Criddle, D.N.; Pinto Duarte, G.I.B.; Santos, M.A.V.; Magalhães, P.J.C. Inhibitory actions of eugenol on rat isolated ileum. Can. J. Physiol. Pharmacol. 2002, 80, 901-906. [CrossRef]

85. Dhifi, W.; Bellili, S.; Jazi, S.; Bahloul, N.; Mnif, W.; Dhifi, W.; Bellili, S.; Jazi, S.; Bahloul, N.; Mnif, W. Essential Oils' Chemical Characterization and Investigation of Some Biological Activities: A Critical Review. Medicines 2016, 3, 25. [CrossRef] [PubMed]

86. Price, S.; Price, L. Aromatherapy for Health Professionals, 3rd ed.; Churchill Livingstone: London, UK, 2007; pp. 385-478. ISBN 10: 0-443-10134-5.

87. Pelkonen, O.; Abass, K.; Wiesner, J. Thujone and thujone-containing herbal medicinal and botanical products: Toxicological assessment. Regul. Toxicol. Pharmacol. 2013, 65, 100-107. [CrossRef] [PubMed]

88. Aprotosoaie, A.C.; Hăncianu, M.; Costache, I.-I.; Miron, A. Linalool: A review on a key odorant molecule with valuable biological properties. Flavour Fragr. J. 2014, 29, 193-219. [CrossRef]

89. Caputo, L.; Souza, L.F.; Alloisio, S.; Cornara, L.; De Feo, V. Coriandrum sativum and Lavandula angustifolia essential oils: Chemical composition and activity on central nervous system. Int. J. Mol. Sci. 2016, 17, 1999. [CrossRef]

90. Lima, C.C.; Criddle, D.N.; Coelho-de-Souza, A.N.; Monte, F.J.Q.; Jaffar, M.; Leal-Cardoso, J.H. Relaxant and Antispasmodic Actions of Methyleugenol on Guinea-Pig Isolated Ileum. Planta Med. 2000, 66, 408-411. [CrossRef]

91. Sousa, P.J.C.; Linard, C.F.B.M.; Azevedo-Batista, D.; Oliveira, A.C.; Coelho-de-Souza, A.N.; Leal-Cardoso, J.H. Antinociceptive effects of the essential oil of Mentha $x$ villosa leaf and its major constituent piperitenone oxide in mice. Brazilian J. Med. Biol. Res. 2009, 42, 655-659. [CrossRef]

92. Bowles, E.J. The Chemistry of Aromatherapeutic Oils, 3rd ed.; Allen \& Unwin: Crows Nest, Australia, 2003; pp. 1-256. ISBN 10:174114051X.

93. Ansari, S.H.; Ali, M.; Qadry, J.S. Essential oils of Pistacia integerrima galls and their effect on the central nervous system. Pharm. Biol. 1993, 31, 89-95. [CrossRef]

94. Shirole, R.L.; Shirole, N.L.; Kshatriya, A.A.; Kulkarni, R.; Saraf, M.N. Investigation into the mechanism of action of essential oil of Pistacia integerrima for its antiasthmatic activity. J. Ethnopharmacol. 2014, 153, 541-551. [CrossRef]

95. Rauf, A. Chemical composition and biological screening of essential oils from Pistacia integerrima. African J. Pharm. Pharmacol. 2014, 7, 1220-1224. [CrossRef] 
96. Benini, C.; Mahy, G.; Bizoux, J.-P.; Wathelet, J.-P.; du Jardin, P.; Brostaux, Y.; Fauconnier, M.-L. Comparative Chemical and Molecular Variability of Cananga odorata (Lam.) Hook.f. \& Thomson forma genuina (Ylang-Ylang) in the Western Indian Ocean Islands: Implication for Valorization. Chem. Biodivers. 2012, 9, 1389-1402. [CrossRef]

97. Brokl, M.; Fauconnier, M.-L.; Benini, C.; Lognay, G.; Jardin, P.; Focant, J.-F. Improvement of Ylang-Ylang Essential Oil Characterization by GCXGC-TOFMS. Molecules 2013, 18, 1783-1797. [CrossRef]

98. Tan, L.T.H.; Lee, L.H.; Yin, W.F.; Chan, C.K.; Abdul Kadir, H.; Chan, K.G.; Goh, B.H. Traditional Uses, Phytochemistry, and Bioactivities of Cananga odorata (Ylang-Ylang). Evid. Based Complement. Alternat. Med. 2015, 896314, 1-30. [CrossRef]

99. Preedy, V.R. Essential oils in food preservation, flavor and safety; Elsevier: New York, USA, 2016; p. 895. ISBN 978-0-12-416641-7.

100. Moura, A.P.G.; Beltrão, D.M.; Pita, J.C.L.R.; Xavier, A.L.; Brito, M.T.; de Sousa, T.K.G.; Batista, L.M.; de Carvalho, J.E.; Ruiz, A.L.T.G.; Della Torre, A.; et al. Essential oil from fruit of Xylopia langsdorffiana: Antitumour activity and toxicity. Pharm. Biol. 2016, 54, 3093-3102. [CrossRef]

101. Rana, V.S.; Blazquez, M.A. Chemical Composition of the Essential Oil of Anethum graveolens Aerial Parts. J. Essent. Oil Bear. Plants 2014, 17, 1219-1223. [CrossRef]

102. Kazemi, M.; Abdossi, V. Chemical composition of the essential oils of Anethum graveolens L. Bangladesh J. Bot. 2015, 44, 159-161. [CrossRef]

103. Stanojević, L.P.; Stanković, M.Z.; Cvetković, D.J.; Danilović, B.R.; Stanojević, J.S. Dill (Anethum graveolens L) seeds essential oil as a potential natural antioxidant and antimicrobial agent. Biol. Nyssana 2016, 7, 31-39. [CrossRef]

104. Rãdulescu, V.; Popescu, M.L.; Ilieş, D.C. Chemical composition of the volatile oil from different plant parts of Anethum graveolens L. (Umbelliferae) cultivated in Romania. Farmacia 2010, 58, 594-600.

105. Mahran, G.H.; Kadry, H.A.; Thabet, C.K.; El-Olemy, M.M.; Al-Azizi, M.M.; Schiff, P.L.; Wong, L.K.; Liv, N. GC/MS Analysis of Volatile Oil of Fruits of Anethum graveolens. Int. J. Pharmacogn. 1992, 30, 139-144. [CrossRef]

106. Charles, D.J.; Simon, J.E.; Widrlechner, M.P. Characterization of Essential Oil of Dill (Anethum graveolens L.). J. Essent. Oil Res. 1995, 7, 11-20. [CrossRef]

107. Chahal, K.K.; Kumar, A.; Bhardwaj, U.; Kaur, R. Chemistry and biological activities of Anethum graveolens L. ( dill ) essential oil: A review. J. Pharmacogn. Phytochem. 2017, 6, 295-306.

108. Ahl, H.A.H.S.; Sarhan, A.M.; Dahab, A.; Dahab, M.A. Essential Oils of Anethum graveolens L.: Chemical Composition and Their Antimicrobial Activities at Vegetative, Flowering and Fruiting Stages of Essential Oils of Anethum graveolens L.: Chemical Composition and Their Antimicrobial Activities at Vegetat. Int. J. Plant Res. 2015, 1, 98-102.

109. Meshkatalsadat, M.H.; Salahvarzi, S.; Aminiradpoor, R.; Abdollahi, A. Identification of essential oil constituents of caraway (Carum carvi) using ultrasonic assist with headspace solid phase microextraction (UA-HS-SPME). Dig. J. Nanomater. Bios. 2012, 7, 637-640.

110. Raal, A.; Arak, E.; Orav, A. The content and composition of the essential oil found in Carum carvi L. commercial fruits obtained from different countries. J. Essent. Oil Res. 2012, 24, 53-59. [CrossRef]

111. Sedláková, J.; Kocourková, B.; Lojková, L.; Kubáň, V. The essential oil content in caraway species (Carum carvi L.). Hortic. Sci. 2018, 30, 73-79. [CrossRef]

112. Orav, A.; Arak, E.; Raal, A. Essential Oil Composition of Coriandrum sativum L. Fruits from Different Countries. J. Essent. Oil-Bear. Plants 2011, 14, 118-123. [CrossRef]

113. Mandal, S.; Mandal, M. Coriander (Coriandrum sativum L.) essential oil: Chemistry and biological activity. Asian Pac. J. Trop. Biomed. 2015, 5, 421-428. [CrossRef]

114. Stefanini; Ming, L.C.; Marques, M.; Meireles, M.A.A.; Moura, L.S. Marchese Seed productivity, yield and composition of the essential oil of fennel Foeniculum vulgare var. dulcis in the season of the year. A Rev. Bras. Plantas Med. 2006, 8, 86-90.

115. Hammouda, F.; Saleh, M.; Abdel-Azim, N.; Shams, K.; Ismail, S.; Shahat, A.; Saleh, I. Evaluation Of The Essential Oil Of Foeniculum Vulgare Mill (Fennel) Fruits Extracted By Three Different Extraction Methods By GC/MS. African J. Tradit. Complement. Altern. Med. 2014, 11, 277-279. [CrossRef] 
116. Miguel, M.G.; Cruz, C.; Faleiro, L.; Simões, M.T.F.; Figueiredo, A.C.; Barroso, J.G.; Pedro, L.G. Foeniculum vulgare essential oils: Chemical composition, antioxidant and antimicrobial activities. Nat. Prod. Commun. 2010, 5, 319-328. [CrossRef]

117. Marín, I.; Sayas-Barberá, E.; Viuda-Martos, M.; Navarro, C.; Sendra, E. Chemical Composition, Antioxidant and Antimicrobial Activity of Essential Oils from Organic Fennel, Parsley, and Lavender from Spain. Foods 2016, 5, 18. [CrossRef]

118. Aprotosoaie, A.C.; Spac, A.; Hancianu, M.; Miron, A.; Tanasescu, V.F.; Dorneanu, V.; Stanescu, U. The chemical profile of essential oils obtained from fennel fruits (Foeniculum vulgare Mill.). Farmacia 2010, 58, $46-53$.

119. Orav, A.; Raal, A.; Arak, E. Essential oil composition of Pimpinella anisum L. fruits from various European countries. Nat. Prod. Res. 2008, 22, 227-232. [CrossRef]

120. Özcan, M.M.; Chalchat, J.C. Chemical composition and antifungal effect of anise (Pimpinella anisum L.) fruit oil at ripening stage. Ann. Microbiol. 2006, 56, 353-358. [CrossRef]

121. Saibi, S.; Belhadj, M.; Benyoussef, E.-H. Essential Oil Composition of Pimpinella anisum from Algeria. Anal. Chem. Lett. 2012, 2, 401-404. [CrossRef]

122. Punetha, V.D. Essential oil composition of Acorus calamus from district - Pithoragarh, Uttarakhad, India. World J. Pharm. Res. 2015, 4, 1158-1166.

123. Raina, V.K.; Srivastava, S.K.; Syamasunder, K.V. Essential oil composition of Acorus calamus L. from the lower region of the Himalayas. Flavour Fragr. J. 2003, 18, 18-20. [CrossRef]

124. Liu, X.C.; Zhou, L.G.; Liu, Z.L.; Du, S.S. Identification of insecticidal constituents of the essential oil of Acorus calamus rhizomes against Liposcelis bostrychophila badonnel. Molecules 2013, 18, 5684-5696. [CrossRef]

125. Verma, R.S.; Padalia, R.C.; Chauhan, A. Chemical Composition of Root Essential Oil of Acorus calamus L. Natl. Acad. Sci. Lett. 2015, 38, 121-125. [CrossRef]

126. Lohani, H.; Andola, H.C.; Chauhan, N.; Bhandari, U. Variations of Essential oil composition of Acorus calamus from Uttarakhand Himalaya. J. Pharm. Res. 2012, 5, 1246-1247.

127. Ayoughi, F.; Barzegar, M.; Sahari, M.A.; Naghdibadi, H. Chemical compositions of essential oils of Artemisia dracunculus L. and endemic Matricaria chamomilla L. and an evaluation of their antioxidative effects. J. Agric. Sci. Technol. 2011, 13, 79-88.

128. Verma, M.K.; Anand, R.; Chisti, A.M.; Kitchlu, S.; Chandra, S.; Shawl, A.S.; Khajuria, R.K. Essential oil composition of Artemisia dracunculus L. (tarragon) growing in Kashmir -India. J. Essent. Oil-Bear. Plants 2010, 13, 331-335. [CrossRef]

129. Asili, J.; Rajabian, A.; Tayarani-Najaran, Z.; Rahimzadeh Oskooie, R.; Emami, S.A.; Hassanzadeh Khayyat, M. Phytochemical Evaluation and Antioxidant Activity of Essential Oil, and Aqueous and Organic Extracts of Artemisia dracunculus. Jundishapur J. Nat. Pharm. Prod. 2017, 12, e32325. [CrossRef]

130. Sayyah, M.; Nadjafnia, L.; Kamalinejad, M. Anticonvulsant activity and chemical composition of Artemisia dracunculus L. essential oil. J. Ethnopharmacol. 2004, 94, 283-287. [CrossRef]

131. Obolskiy, D.; Pischel, I.; Feistel, B.; Glotov, N.; Heinrich, M. Artemisia dracunculus L. (Tarragon): A Critical Review of Its Traditional Use, Chemical Composition, Pharmacology, and Safety. J Agric Food Chem. 2011, 59, 11367-11384. [CrossRef] [PubMed]

132. Irfan-ur-Rauf, T.; Dawood, M.; Ganai, B.A.; Chishti, M.Z.; Fayaz, A.; Jehangir, S.D. Phytochemical studies on the extract and essential oils of Artemisia dracunculus L. (Tarragon). African J. Plant Sci. 2014, 8, 72-75. [CrossRef]

133. Srivastava, J.K.; Shankar, E.; Gupta, S. Chamomile: A herbal medicine of the past with bright future. Mol. Med. Rep. 2010, 3, 895-901. [CrossRef] [PubMed]

134. Gardiner, P. Complementary, holistic, and integrative medicine: Chamomile. Pediatr. Rev. 2007, 28 , e16-8. [CrossRef] [PubMed]

135. Sharafzadeh, S.; Alizadeh, O. German and roman chamomile. J. Appl. Pharm. Sci. 2011, 1, 1-5.

136. Aremu, O.O.; Tata, C.M.; Sewani-rusike, C.R. Phytochemical composition, and analgesic and antiinflammatory properties of essential oil of Chamaemelum nobile (Asteraceae L All) in rodents. Trop. J. Pharm. Res. 2018, 17, 1939-1945. [CrossRef]

137. De Groot, A.C.; Schmidt, E. Essential Oils, Part III: Chemical Composition. Dermatitis 2016, 27, 161-169. [CrossRef] 
138. Al-snafi, A.E. Medical importance of Anthemis nobilis (Chamaemelum nobile)—A review. Asian J. Pharm. Sci. Technol. 2016, 6, 89-95.

139. Cárdenas-Ortega, N.C.; Zavala-Sánchez, M.A.; Aguirre-Rivera, J.R.; Pérez-González, C.; Pérez-Gutiérrez, S. Chemical Composition and Antifungal Activity of Essential Oil of Chrysactinia mexicana Gray. J. Agric. Food Chem. 2005, 53, 4347-4349. [CrossRef] [PubMed]

140. Pérez-Vásquez, A.; Capella, S.; Linares, E.; Bye, R.; Angeles-López, G.; Mata, R. Antimicrobial activity and chemical composition of the essential oil of Hofmeisteria schaffneri. J. Pharm. Pharmacol. 2011, 63, 579-586. [CrossRef]

141. Mousavi, E.S.; Dehghanzadeh, H.; Abdali, A. Chemical Composition and Essential Oils of Pelargonium graveolens (Geraniaceae) By Gas Chromatography-Mass Spectrometry (GC/MS). Bull. Env. Pharmacol. Life Sci. 2014, 3, 182-184.

142. Boukhris, M.; Simmonds, M.S.J.; Sayadi, S.; Bouaziz, M. Chemical Composition and Biological Activities of Polar Extracts and Essential Oil of Rose-scented Geranium, Pelargonium graveolens. Phytother. Res. 2013, 27, 1206-1213. [CrossRef]

143. Rana, V.S.; Juyal, J.P.; Amparo Blazquez, M. Chemical constituents of essential oil of Pelargonium graveolens leaves. Int. J. Aromather. 2002, 12, 216-218. [CrossRef]

144. Sharopov, F.S.; Zhang, H.; Setzer, W.N. Composition of geranium (Pelargonium graveolens) essential oil from Tajikistan. Am. J. Essent. Oils Nat. Prod. 2014, 2, 13-16.

145. Tarakemeh, A.; Rowshan, V.; Najafian, S. Essential Oil Content and Composition of Lavandula Angustifolia Mill. as Affected by Drying Method and Extraction Time. Anal. Chem. Lett. 2013, 2, 244-249. [CrossRef]

146. Mirensha; Wang, X.; Zhi, L.; Cong, Y.; Abulizi, P. Chemical composition of the essential oil of Lavandula angustifolia from Xinjiang, China. Chem. Nat. Compd. 2009, 44, 810. [CrossRef]

147. Smigielski, K.; Prusinowska, R.; Stobiecka, A.; Kunicka-Styczyñska, A.; Gruska, R. Biological Properties and Chemical Composition of Essential Oils from Flowers and Aerial Parts of Lavender (Lavandula angustifolia). J. Essent. Oil-Bear. Plants 2018, 21, 1303-1314. [CrossRef]

148. SSerban, E.S.; Socaci, S.A.; Tofană, M.; Maier, S.C.; Bojiţă, M.T. Chemical composition of some essential oils of Lamiaceae family. Clujul Med. 2010, LXXXIII, 286-289.

149. Abdellatif, F; Hassani, A. Chemical composition of the essential oils from leaves of Melissa officinalis extracted by hydrodistillation, steam distillation, organic solvent and microwave hydrodistillation. J. Mater. Environ. Sci. 2015, 6, 207-213.

150. Verma, R.S.; Padalia, R.C.; Chauhan, A. Evaluation of essential oil quality of lemon balm ( Melissa officinalis L.) grown in two locations of northern India. J. Essent. Oil Res. 2015, 27, 412-416. [CrossRef]

151. Chizzola, R.; Lohwasser, U.; Franz, C. Biodiversity within Melissa officinalis: Variability of Bioactive Compounds in a Cultivated Collection. Molecules 2018, 23, 294. [CrossRef] [PubMed]

152. Efremov, A.A.; Zykova, I.D.; Gorbachev, A.E. Composition of the essential oil from the lemon balm growing in the neighborhood of Krasnoyarsk as indicated by gas chromatography-mass spectrometry data. Russ. J. Bioorganic Chem. 2017, 42, 726-729. [CrossRef]

153. Taherpour, A.A.; Khaef, S.; Yari, A.; Nikeafshar, S.; Fathi, M.; Ghambari, S. Chemical composition analysis of the essential oil of Mentha piperita L. from Kermanshah, Iran by hydrodistillation and HS/SPME methods. J. Anal. Sci. Technol. 2017, 8, 11. [CrossRef]

154. Moghaddam, M.; Pourbaige, M.; Tabar, H.K.; Farhadi, N.; Hosseini, S.M.A. Composition and Antifungal Activity of Peppermint (Mentha piperita) Essential Oil from Iran. J. Essent. Oil-Bear. Plants 2013, 16, 506-512. [CrossRef]

155. Shahi, A.K.; Chandra, S.; Dutt, P.; Kaul, B.L.; Tava, A.; Avato, P. Essential oil composition of Mentha x piperita L. from different environments of north India. Flavour Fragr. J. 1999, 14, 5-8. [CrossRef]

156. Ainane, A. Chemical Study by GC-MS of the Essential Oils of Certain Mints Grown In the Region of Settat (Morocco): Mentha Piperita, Mentha Pulegium and Mentha Spicata. Drug Des. Intellect. Prop. Int. J. 2018, 1, 124-127. [CrossRef]

157. Hussain, A.I.; Anwar, F.; Shahid, M.; Ashraf, M.; Przybylski, R. Chemical Composition, and Antioxidant and Antimicrobial Activities of Essential Oil of Spearmint ( Mentha spicata L.) From Pakistan. J. Essent. Oil Res. 2010, 22, 78-84. [CrossRef] 
158. Snoussi, M.; Noumi, E.; Trabelsi, N.; Flamini, G.; Papetti, A.; De Feo, V. Mentha spicata essential oil: Chemical composition, antioxidant and antibacterial activities against planktonic and biofilm cultures of vibrio spp. strains. Molecules 2015, 20, 14402-14424. [CrossRef] [PubMed]

159. Lahlou, S.; Carneiro-Leão, R.F.L.; Leal-Cardoso, J.H.; Toscano, C.F. Cardiovascular Effects of the Essential Oil of Mentha x villosa and its Main Constituent, Piperitenone Oxide, in Normotensive Anaesthetised Rats: Role of the Autonomic Nervous System. Planta Med. 2001, 67, 638-643. [CrossRef] [PubMed]

160. Lima, T.C.; da Silva, T.K.M.; Silva, F.L.; Barbosa-Filho, J.M.; Marques, M.O.M.; Santos, R.L.C.; de Holanda Cavalcanti, S.C.; de Sousa, D.P. Larvicidal activity of Mentha $x$ villosa Hudson essential oil, rotundifolone and derivatives. Chemosphere 2014, 104, 37-43. [CrossRef] [PubMed]

161. Fogaca, R.T.H.; Cavalcante, A.D.A.; Serpa, A.K.L.; Sousa, P.J.C.; Coelho-de-Souza, A.N.; Leal-Cardoso, J.H. The effects of essential oil of Mentha x villosa on skeletal muscle of the toad. Phytother. Res. 1997, 11, 552-557. [CrossRef]

162. Pandey, A.K.; Singh, P.; Tripathi, N.N. Chemistry and bioactivities of essential oils of some Ocimum species: An overview. Asian Pac. J. Trop. Biomed. 2014, 4, 682-694. [CrossRef]

163. Costa, L.C.B.; Pinto, J.E.B.P.; Castro, E.M.; Alves, E.; Rosal, L.F.; Bertolucci, S.K.V.; Alves, P.B.; Evangelino, T.S. Yield and Composition of the Essential Oil of Ocimum selloi Benth. Cultivated Under Colored Netting. J. Essent. Oil Res. 2010, 22, 34-39. [CrossRef]

164. Moraes, L.A.S.; Facanali, R.; Marques, M.O.M.; Lin, C.M.; Meireles, M.A.A. Phytochemical characterization of essential oil from Ocimum selloi. An. Acad. Bras. Cienc. 2002, 74, 183-186. [CrossRef] [PubMed]

165. Chimnoi, N.; Reuk-ngam, N.; Chuysinuan, P.; Khlaychan, P.; Khunnawutmanotham, N.; Chokchaichamnankit, D.; Thamniyom, W.; Klayraung, S.; Mahidol, C.; Techasakul, S. Characterization of essential oil from Ocimum gratissimum leaves: Antibacterial and mode of action against selected gastroenteritis pathogens. Microb. Pathog. 2018, 118, 290-300. [CrossRef]

166. Madeira, S.V.F.; Rabelo, M.; Soares, P.M.G.; Souza, E.P.; Meireles, A.V.P.; Montenegro, C.; Lima, R.F.; Assreuy, A.M.S.; Criddle, D.N. Temporal variation of chemical composition and relaxant action of the essential oil of Ocimum gratissimum L. (Labiatae) on guinea-pig ileum. Phytomedicine 2005, 12, 506-509. [CrossRef] [PubMed]

167. Rus, C.; POP, G.; Alexa, E.; Renata, M.S.; Dana, M.C. Antifungal activity and chemical composition of Origanum majorana L. essential oil. Res. J. Agric. Sci. 2015, 47, 179-185.

168. Komaitis, M.E.; Ifanti-Papatragianni, N.; Melissari-Panagiotou, E. Composition of the essential oil of marjoram (Origanum majorana L.). Food Chem. 1992, 45, 117-118. [CrossRef]

169. Brada, M.; Saadi, A.; Wathelet, J.P.; Lognay, G. The essential oils of Origanum majorana 1. and Origanum floribundum munby in Algeria. J. Essent. Oil-Bear. Plants 2012, 15, 497-502. [CrossRef]

170. Raina, A.P.; Negi, K.S. Essential oil composition of Origanum majorana and Origanum vulgare ssp. hirtum growing in India. Chem. Nat. Compd. 2012, 47, 1015-1017. [CrossRef]

171. Bağci, Y.; Kan, Y.; Doğu, S.; Çelik, S.A. The essential oil compositions of Origanum majorana L. cultivated in Konya and collected from Mersin-Turkey. Indian J. Pharm. Educ. Res. 2017, 51, S463-S469. [CrossRef]

172. Alasbahi, R.; Melzig, M. Plectranthus barbatus: A Review of Phytochemistry, Ethnobotanical Uses and Pharmacology - Part 1. Planta Med. 2010, 76, 653-661. [CrossRef]

173. Kerntopf, M.R.; de Albuquerque, R.L.; Machado, M.I.L.; Matos, F.J.A.; Craveiro, A.A. Essential Oils from Leaves, Stems and Roots of Plectranthus barbatus Andr. (Labiatae) Grown in Brazil. J. Essent. Oil Res. 2002, 14, 101-102. [CrossRef]

174. Galvão Rodrigues, F.F.; Costa, J.G.M.; Rodrigues, F.F.G.; Campos, A.R. Study of the Interference between Plectranthus Species Essential Oils from Brazil and Aminoglycosides. Evid. Based. Complement. Alternat. Med. 2013, 724161, 1-7. [CrossRef]

175. Adel, K.; Zied, Z.; Ben Choba, I.; Bekir, A.; Gharsallah, N.; Damak, M.; Gdoura, R. Chemical constituents and antioxidant properties of Rosmarinus officinalis L. essential oil cultivated from the South-Western of Tunisia. J. Med. Plants Res. 2011, 5, 5999-6004. [CrossRef]

176. Belkhodja, H.; Meddah, B.; Touil, A.T.; Şekeroğlu, N.; Sonnet, P. Chemical Composition and Properties of Essential Oil of Rosmarinus Officinalis and Populus Alba. World J. Pharm. Pharm. Sci. 2016, 5041, 108-119. [CrossRef]

177. Satyal, P.; Jones, T.H.; Lopez, E.M.; McFeeters, R.L.; Ali, N.A.A.; Mansi, I.; Al-Kaf, A.G.; Setzer, W.N. Chemotypic Characterization and Biological Activity of Rosmarinus officinalis. Foods 2017, 6, 20. [CrossRef] 
178. Gezici, S.; Karik, U.; Sekeroglu, N.; Tuncturk, M.; Cinar, O. Essential Oil Composition of Some Sage (Salvia spp.) Species Cultivated in İzmir (Turkey) Ecological Conditions. Indian J. Pharm. Educ. Res. 2018, 52, s102-s107. [CrossRef]

179. Khedher, M.R.B.; Khedher, S.B.; Chaieb, I.; Tounsi, S.; Hammami, M. Chemical composition and biological activities of Salvia officinalis essential oil from Tunisia. EXCLI J. 2017, 16, 160-173. [CrossRef]

180. Mohammadhosseini, M.; Beiranvand, M. Chemical Composition of the Essential Oil from the Aerial Parts of Satureja hortensis As a Potent Medical Plant Using Traditional Hydrodistillation. J. Chem. Health Risks 2013, 3, 49-60.

181. Mihajilov-Krstev, T.; Radnović, D.; Kitić, D.; Zlatković, B.; Ristić, M.; Branković, S. Chemical composition and antimicrobial activity of Satureja hortensis L. essential oil. Open Life Sci. 2009, 4, 411-416. [CrossRef]

182. Matasyoh, J.; Wagara, I.; Nakavuma, J.; Kiburai, A. Chemical composition of Cymbopogon citratus essential oil and its effect on mycotoxigenic Aspergillus species. African J. Food Sci. 2011, 5, 138-142.

183. Mohamed Hanaa, A.R.; Sallam, Y.I.; El-Leithy, A.S.; Aly, S.E. Lemongrass (Cymbopogon citratus) essential oil as affected by drying methods. Ann. Agric. Sci. 2012, 57, 113-116. [CrossRef]

184. Machraoui, M.; Kthiri, Z.; Ben Jabeur, M.; Hamada, W. Ethnobotanical and phytopharmacological notes on Cymbopogon citratus ( DC.) Stapf. J. New Sci. Agric. Biotechnol. 2018, 55, 3642-3652.

185. Akhila, A. Essential Oil-Bearing Grasses: The genus Cymbopogon; CRC Press: Boca Raton, FL, USA, $2010 ;$ p. 284. ISBN 978-0-8493-7857-7.

186. Raina, V.K.; Srivastava, S.K.; Aggarwal, K.K.; Syamasundar, K.V.; Khanuja, S.P.S. Essential oil composition of Cymbopogon martinii from different places in India. Flavour Fragr. J. 2003, 18, 312-315. [CrossRef]

187. Gupta, R.; Mallavarapu, G.R.; Ramesh, S.; Kumar, S. Composition of flower essential oils of Rosa damascena and Rosa indica grown in Lucknow. J. Med. Aromat. Plant Sci. 2000, 22, 9-12.

188. Dugo, G.; Mondello, L. Citrus oils: Composition, advanced analytical techniques, contaminants, and biological activity; CRC Press: Boca Raton, FL, USA, 2011; p. 642. ISBN 0415-28491-0.

189. Garza-González, E.; Alvarez, L.; Sandoval-Montemayor, N.E.; del Rayo Camacho-Corona, M.; García, A.; Elizondo-Treviño, E. Chemical Composition of Hexane Extract of Citrus aurantifolia and Anti-Mycobacterium tuberculosis Activity of Some of Its Constituents. Molecules 2012, 17, 11173-11184. [CrossRef]

190. Azar, P.A.; Nekoei, M.; Larijani, K.; Bahraminasab, S. Chemical composition of the essential oils of Citrus sinensis $\mathrm{cv}$. Valencia and a quantitative structure-retention relationship study for the prediction of retention indices by multiple linear regression. J. Serbian Chem. Soc. 2011, 76, 1627-1637. [CrossRef]

191. Njoroge, S.M.; Phi, N.T.L.; Sawamura, M. Chemical Composition of Peel Essential Oils of Sweet Oranges (Citrus sinensis) from Uganda and Rwanda. J. Essent. Oil-Bear. Plants 2009, 12, 26-33. [CrossRef]

192. Mamun-Or-Rashid, A.N.M.; Sen, M.K.; Jamal, M.A.H.M.; Nasrin, S. A Comprehensive Ethnopharmacological Review on Lippia Alba M. Int. J. Biomed. Mater. Res. 2014, 1, 14-20. [CrossRef]

193. Juiz, P.J.L.; Lucchese, A.M.; Gambari, R.; Piva, R.; Penolazzi, L.; Di Ciano, M.; Uetanabaro, A.P.T.; Silva, F.; Avila-Campos, M.J. Essential oils and isolated compounds from Lippia alba leaves and flowers: Antimicrobial activity and osteoclast apoptosis. Int. J. Mol. Med. 2015, 35, 211-217. [CrossRef] [PubMed]

194. Machado, T.F.; Nogueira, N.A.P.; de Cássia Alves Pereira, R.; de Sousa, C.T.; Batista, V.C.V. The antimicrobial efficacy of Lippia alba essential oil and its interaction with food ingredients. Braz. J. Microbiol. 2014, 45, 699-705. [CrossRef] [PubMed]

195. Glamočlija, J.; Soković, M.; Tešević, V.; Linde, G.A.; Colauto, N.B. Chemical characterization of Lippia alba essential oil: An alternative to control green molds. Braz. J. Microbiol. 2011, 42, 1537-1546. [CrossRef]

196. Silva, S.G.; da Costa, R.A.; de Oliveira, M.S.; da Cruz, J.N.; Figueiredo, P.L.B.; Brasil, D.D.S.B.; Nascimento, L.D.; Chaves Neto, A.M.D.J.; de Carvalho Junior, R.N.; Andrade, E.H.D.A. Chemical profile of Lippia thymoides, evaluation of the acetylcholinesterase inhibitory activity of its essential oil, and molecular docking and molecular dynamics simulations. PLoS ONE 2019, 14, e0213393. [CrossRef]

197. Silva, F.S.; Menezes, P.M.N.; de Sá, P.G.S.; Oliveira, A.L.D.S.; Souza, E.A.A.; Almeida, J.R.G.D.S.; de Lima, J.T.; Uetanabaro, A.P.T.; Silva, T.R.D.S.; Peralta, E.D.; et al. Chemical composition and pharmacological properties of the essential oils obtained seasonally from Lippia thymoides. Pharm. Biol. 2016, 54, 25-34. [CrossRef]

198. Mahmud, S. Composition of essential oil of Elettaria cardamomum Maton leaves. Pak. J. Sci. 2008, 60, 111-114.

199. Leela, N.K.; Prasath, D.; Venugopal, M.N. Essential oil composition of selected cardamom genotypes at different maturity levels. Indian J. Hortic. 2008, 65, 366-369. 
200. Masoumi-Ardakani, Y.; Mandegary, A.; Esmaeilpour, K.; Najafipour, H.; Sharififar, F.; Pakravanan, M.; Ghazvini, H. Chemical Composition, Anticonvulsant Activity, and Toxicity of Essential Oil and Methanolic Extract of Elettaria cardamomum. Planta Med. 2016, 82, 1482-1486. [CrossRef] [PubMed]

201. Noumi, E.; Snoussi, M.; Alreshidi, M.M.; Rekha, P.-D.; Saptami, K.; Caputo, L.; De Martino, L.; Souza, L.F.; Msaada, K.; Mancini, E.; et al. Chemical and Biological Evaluation of Essential Oils from Cardamom Species. Molecules 2018, 23, 2818. [CrossRef] [PubMed]

202. Kumar, A.; Tandon, S.; Ahmad, J.; Yadav, A.; Kahol, A.P. Essential Oil Composition of Seed and Fruit Coat of Elettaria cardamomum from South India. J. Essent. Oil-Bear. Plants 2005, 8, 204-207. [CrossRef]

(C) 2019 by the authors. Licensee MDPI, Basel, Switzerland. This article is an open access article distributed under the terms and conditions of the Creative Commons Attribution (CC BY) license (http://creativecommons.org/licenses/by/4.0/). 